\title{
Det mandlige herredømme i middelhavskulturen ifølge Pierre Bourdieu
}

\author{
Staf Callewaert og Karin Anna Petersen \\ Professor emeritus i pædagogik, Københavns Universitet \\ Professor i sykepleievitenskap, Universitetet i Bergen
}

\section{Sammendrag}

Den feministiske kritiks mistanke om, at mandlige skrifter om forskellen mellem de to $k \varnothing n$ omfatter fordomme, er berettiget. Den mandlige analytiker kan ud fra en forsvarsholdning komme til at tilskrive de agenter, han analyserer, forudsætninger og fordomme, som i virkeligheden er de forudsætninger og fordomme, han selv går ud fra i sin analyse. Men frem for alt er forskellen mellem de to køn en institution, som gennem tusinder af år er indskrevet i de objektive, sociale strukturer og de subjektive mentale strukturer sådan, at forskeren er tvunget til at bruge dét som erkendelsesmidler, der burde være formål for analysen, nemlig de kategorier vi bruger for at tænke problemet.

Teksten er en resumerende fortolkning af Pierre Bourdieus artikel om det mandlige herred $\varnothing \mathrm{mme}$ : Bourdieu, P (1990): La Domination Masculine. Actes de la recherche en sciences socialcs, 84, Paris 231. Fortolkningen prøver med nogle minimale kommentarer at indfange de store linjer i opfattelsen.

Keywords: praxeologi, kønssociologi, etnologi, social arbejdsdeling, feminisme, Pierre Bourdieu, Virginia Woolf

\footnotetext{
Teksten er en resumerende fortolkning af Pierre Bourdieus artikel om det mandlige herredømme: Bourdieu (1990). Fortolkningen prøver med nogle minimale kommentarer at indfange de store linjer i opfattelsen. Teksten er tidligere publiceret i Callewaert et al. (Red.)(1994-2008), s. 20-48. Forfatterne takker Frydenlund for tilladelsen til at bringe teksten her.
}

Publisert: 06.08.2020

Praxeologi - Et kritisk refleksivt blikk på sosiale praktikker (C2020 Staf Callewaert \& Karin Anna Petersen 


\section{Indledning}

Den feministiske kritiks mistanke om, at mandlige skrifter om forskellen mellem de to $k \varnothing n$ omfatter fordomme, er berettiget. Den mandlige analytiker kan ud fra en forsvarsholdning komme til at tilskrive de agenter, han analyserer, forudsætninger og fordomme, som i virkeligheden er de forudsætninger og fordomme, han selv går ud fra i sin analyse. Men frem for alt er forskellen mellem de to køn en institution, som gennem tusinder af år er indskrevet i de objektive, sociale strukturer og de subjektive mentale strukturer sådan, at forskeren er tvunget til at bruge dét som erkendelsesmidler, der burde være formål for analysen, nemlig de kategorier vi bruger for at tænke problemet.

Som eksempel citerer Bourdieu en tekst af Jacques Lacan, som kun giver udtryk for de sædvanlige sociale fantasmer omkring $k \emptyset n n e t$, men foregiver at være en videnskabelig forklaring. Bourdieu er antropolog specialiseret på middelhavsområdets kulturer med deres dyrkelse af maskuliniteten. Han vender analysens instrument mod selve analytikerens arbejde, og har ikke svært ved at identificere en phallo-narcissistisk personlighed hos Jacques Lacan. Lacan er styret af det mandlige fremfor det kvindelige eller barnlige, og han elsker at blive dyrket af omgivelserne. Hos Lacan slår et ikkeanalyseret, ubevidst element igennem, for eksempel i hans teoretiske ordlege. Måske henter han netop de tankekategorier uden at vide det, ud fra de ikke-tænkte regioner af sit ubevidste, med hvilke han forsøger at tænke det ubevidste.

I den forstand er det vigtigt med systematiske antropologiske analyser af psykoanalytiske tekster. Sådan kan man for eksempel allerede hos Sigmund Freud se, hvordan den biologiske forskel mellem det kvindelige og det mandlige $k \varnothing n$ konstitueres som en biologisk defekt hos kvindekønnet, som er etisk mindreværdigt.

Dette gør livet svært for feministiske psykoanalytikere, der er positivt eller negativt inspireret af Sigmund Freud. I og med at psykoanalysen generelt uden kritik har accepteret alle postulater i det fremherskende mandlige syn, så bliver det en svær opgave at vide, hvad man accepterer, og hvad man forkaster. Det er svært at vide, om man forkaster netop det maskulinistiske budskab eller bare den essentialistiske, naturaliserede opfattelse af $k \emptyset n$ eller den mindreværdige position, som de sociale vilkår tildeler kvinden.

En vej ud af denne cirkel er at foretage en antropologisk analyse af en fremmed og alligevel fortrolig, kollektiv mytologi, som for eksempel kabylernes i Algeriet, der har bevaret en urgammel forankring i middelhavsområdets trosforestillinger, organiseret omkring en kult af mandlighed. Den består af diskurser og ritualer indrettede på reproduktionen af en social og kosmisk ordning, forankret i en ultrakonsekvent hævdelse af mandlighedens primat. Man kan sige, at denne kultur tilbyder et forstørret og systematiseret billede af den phallonarcissistiske kosmologi, som findes i vores kollektive ubevidste.

Læg mærke til, at Bourdieu udtrykkelig skelner mellem på den ene side den antropologiske analyse af samfundets forvaltning af den mandlige og den kvindelige dimension af personligheden og på den anden siden den psykoanalytiske analyse af samme.

Den kollektive mytologi reproducerer sig via de socialiserede kroppe, dvs. via habitus og via rituelle praktikker, mere end via den individuelle hukommelse. Det, som er effektivt, er ikke forestillinger vi husker, men kroppens praktikker.

En sådan antropologisk analyse af et system er bedre end en komparativ undersøgelse af forskellige systemer, fordi logikken i modstillingerne bedre kommer frem, når man studerer ét system. En komparativ analyse synliggør derimod det relativt vilkårlige netop i modstillingen mandligt/ kvindeligt i det system af homologe modstillinger, hvor den naturaliseres. Således mener eskimoerne for eksempel, at månen er mandlig og solen kvindelig; manden identificeres med det rå, det kolde og naturen, kvinden med det kogte, det varme og kulturen. Altsammen lige modsat 
middelhavsmodellen. Dette forhindrer ikke, at også eskimoerne henviser kvinden til en underordnet rolle, begrænset til husets fire vægge.

Den kollektive mytologi omkring køn som opdelingsprincip træder meget bedre frem i en kultur, hvor den selv i dag viser sig i både de objektive strukturer og de kollektive og offentlige udtryksformer (Kabylien), i stedet for kun at fremkomme under konfrollerede former i digtning eller den analytiske kur (Frankrig).

Når man for eksempel ser på studier omkring "æren" i hele middelhavsområdet fra antikken til i dag, så handler det om en kultur med en vis enhed. Derfor kunne man også gennemføre analysen med den græske oldtid som materiale. Og den græske oldtids kulturelt ubevidste er fundamentalt det samme som vores kulturelt ubevidste i Frankrig og Europa. Det er dog afgørende, at man er bevidst om, at den finlitterære tradition fra oldtiden til i dag ikke lader den kollektive mytologi fremtræde klart. Man er tvunget til at gå en omvej over ældre tekster som Homeros eller de præsokratiske filosoffer, som repræsenterer en mindre censureret version af traditionen. På det punkt begår Michel Foucault en fejl, når han begynder med Platon i seksualitetens historie.

I det hele taget er det svært at lade en antropologisk analyse tage sit udgangspunkt i litterære tekster. De er allerede selv et produkt af en antropologisk analyse ved forfatterne, mens vi anvender dem som udsagn af førstehåndsinformanter om den kollektive mytologi.

Den litterære bearbejdning kan man for eksempel se i, hvordan kvinden fra begyndelsen tænkes analog med marken, som bliver pløjet af den (mandlige) plov; med ovnen, hvor brødet bages; eller i de litterære tekster analog med den tavle, på hvilken man (manden) skriver.

En anden vanskelighed opstår i og med, at en litterær tradition overleverer materialet til stadige omfortolkninger og til sidst ender i en slags synkron kortslutning, hvor de forskellige lag er forsvundet.

\section{Den symbolske vold: Et tvangsmiddel via kroppen}

Det mandlige herredømme er så sikkert, at det ikke behøver at blive retfærdiggjort. Det kan nøjes med at komme til udtryk i praktikker og diskurser som noget selvfølgeligt; det der siges, omsættes til det, som er.

Man kan dog ikke anvende ordet ideologi om den kollektive myte. Den opstår og hævdes ikke med den hensigt at legitimere en social orden. Selv om den naturligvis får en legitimerende effekt som bivirkning. Til og med i de differentierede samfund er legitimeringen ikke en tilstræbt effekt (jf. skolens rolle i moderne samfund). Dette er endnu tydeligere i samfund som det kabylske, hvor hele den sociale orden er ét eneste symbolsk maskineri med det mandlige herredømme som sin kerne.

Det mandlige herredømme er en måde at gestalte opdelingen mellem det mandlige og det kvindelige. Det udtrykker sig i:

- diskurser (ordsprog, talemåder, gåder, sange og digte)

- grafiske dekorationer af vægge

- opdelingen af tiden

- sociale og tekniske praktikker

- kropsteknikker

Det mandlige herredømme lader til at være normalt, naturligt, uundgåeligt, fordi det findes både i de objektive sociale strukturer og i de tilsvarende mentale strukturer som forkropsliggjorte strukturer, der bliver til et universelt princip af iagttagelse, tænkning og handlen. Denne overensstemmelse af det ydre og det indre giver som resultat den "doksiske" erfaring. Det vil sige: Man erfarer det mandlige herredømme som noget så selvfølgeligt, at det ikke opleves som sådan, endsige bliver 
problematiseret af afvigende forestillinger. Dette er den stærkeste form for legitimitet: Ingen kommer på den tanke, at det skal være eller behøver at blive legitimeret. Mens det i virkeligheden handler om noget vilkårligt, der er socialt konstrueret.

I den forbindelse spiller universaliteten af det mandlige herredømme en stor rolle: Den normale anledning til, at det selvfølgelige bliver relativeret, nemlig at man opdager, at nabo-kulturen ser sagen på en helt andet måde, har i meget stor udstrækning været savnet.

De (omvendte) "valg", der naturaliseres i "doxaen", undgår at fremstå som det, de er, nemlig vilkårlige, historisk instituerede, forankret i loven og sædvaner og ikke i naturen. "Doxaen" tillader den ene part (manden) at fremstå som den eneste repræsentant for helheden (mennesket).

Hos kabylerne for eksempel er "en mand af ære" det højeste menneskelige niveau. Det højeste menneske kan kun være en mand, og alle dets dyder er mandlige dyder. Heltens voldelighed, krigerens mod og mandens seksuelle potens er altsammen en del af "æren", af det højeste menneskelige niveau.

Det mandlige herredømme er indskrevet i de institutionaliserede (instituerede) sociale relationer af undertrykkelse og udbytning og i de mentale strukturer som klassifikationsprincip for alle formål og praktikker. Dette $g \varnothing r$, at det hele tiden bliver bevaret.

I og med at opdelingen og rangordenen fremstår som forankret i det biologiske og de facto er universel, så findes der ingen grund til ikke at se den som normal, naturlig og uundgåelig.

Det, der sker, er altså, at kvinderne som konkrete individer klassificeres som kvindelige, og modstillingen kvindeligt / mandligt indlejres i det globale kulturelle modsætningssystem. Kvindeligt ses på linje med det indre, det fugtige, det lavere, det bøjede, det indesluttede. Alle huslige gøremål tilfalder kvinden, de er private og skjulte, usynlige og skanmfulde. Hun tilegnes også en stor del af gøremålene uden for huset, nemlig de der har at gøre med det grønne, det fugtige (vandet, rengøring, beplantningen), mælk, brænde, dvs. de gøremål der er snavsede, monotone, besværlige og uglamourøse. På samme måde henvises manden til det mandlige, som falder sammen med det ydre, det officielle, det offentlige, det rå, det tørre, det $\varnothing v r e$, det diskontinuerlige, det vil sige alle handlinger, som er kortvarige, farlige og spekulative (pløje og så, slagte dyr, myrde og bekrige, anvende ild og fabrikere instrumenter...).

Fordelingen af sager og aktiviteter mellem det, der hører under det kvindelige og det, der hører under det mandlige, er vilkårlig, hvis man betragter det isoleret (og det mærkes tydeligst af, at det somme tider i nabokulturen er lige modsat). Men det får en slags subjektiv og objektiv nødvendighed af, at det indgår i et system af homologe modstillinger: $\mathrm{H} \varnothing \mathrm{j} / \mathrm{lav}$, over/under, foran/bagved, højre/venstre, ret/bøjet, tør/fugtig, hård/blød, krydret/smagløs, lyst/mørkt, Alle disse modstillinger er tilstrækkelig forskellige til at kunne bidrage med karakteristika til den totale klassificerede virkelighedsbeskrivelse, men tilstrækkelig ens til at kunne bekræfte hinanden. Dette forårsages også af et spil af metaforer, associationer og konnotationer.

Den herredømmerelation, der ligger til grund for kønsopdelingen, har under disse omstændigheder ingen chance for at komme frem i lyset. Det forhold, der er årsag, fremstår som effekt, som en konsekvens af tingenes mening, der eksisterer helt uafhængigt af magtforhold.

Det vigtige er at se, at det der er sociale relationer ikke bare bliver perciperet, opfattet og varetaget, som om de var naturlige ting, men at netop den naturalisering sker gennem en somatisering eller kropsliggørelse: Vi får to fuldstændige og modsatte systemer af det naturligtmandlige og det naturligt-kvindelige, som hver for sig består dels af et system af kropsholdninger, måder at gå og røre sig på, gebærden etc., dels af et mentalt klassificeringssystem, som både iagttager og initierer disse kropslige måder at gebærde sig på, og som ved et under stemmer overens med de modstillinger, de har været med til at udforme. 
På den måde kan man for eksempel ud fra modstillingen mellem det rette og det runde, det retlinede og det bøjede, generere alle andre modstillinger, som drejer sig om etiske dispositioner eller måden at anvende kroppen på.

Den negative forudfattede mening, der hæfter sig ved det kvindelige som modpolen til det mandlige i overensstemmelse med en social institution og som en del af den sociale ordning, har gennemslagskraft på det symbolske plan, fordi den fungerer som en selvopfyldende profeti. Dette sker ved hjælp af en anden mekanisme, som er "kærligheden til skæbnen", dvs. tendensen hos ofrene til at hengive sig til den skæbne, som de er socialt forudbestemt til.

Den forudfattede positive mening, der hæfter sig ved det mandlige, fungerer på samme måde, hvilket man gerne glemmer.

Når kabylske kvinder "elsker" at bruge deres tid på at regne, beregne, forudse, gøre små gevinster etc., noget som en mand af ære i hvert fald lader som om han aldrig kunne tænke sig at beskæftige sig med, så er det en god illustration af den mekanisme, vi har udpeget.

Disse kvinder virkeligg ør det billede af sig selv, som manden tvinger dem til og giver på den måde en slags naturligt fundament til en social opdeling, der er påtvungen. Den gensidige bekræftelse af forventet opførsel og observerbar opførsel indespærrer både mænd og kvinder i en cirkel af spejlinger, som i det uendelige spejler antagonistiske billeder, der bekræfter hinanden. Da urbjerget, det hele bygger på, aldrig blottes, bliver det aldrig tydeligt, at kvinderne er listige eller intuitive, fordi de har været tvunget til at være det. Det bøjede leder til det skurkagtige. Kvindens styrke ligger $\mathrm{i}$ måden at anvende sin underkastelse på, det vil sige i listigheden. Kun ved at træde i baggrunden og afstå fra at udøve magt kan kvinden påtage sig rollen af grå eminence eller udøve magt gennem ombud. Hvilket leder til, at systemet af forbud, som skal kontrollere kvindernes ondskabsfulde natur, fremstår berettiget.

Det man plejer at kalde for den kvindelige intuition er bare en variant af en hvilken som helst undertrykts skarpsindighed $\mathrm{i}$ kampen for at overleve. En hollandsk unders $\varnothing$ gelse har for eksempel vist, at kvinder kan beskrive deres mænd i alle detaljer, mens mænd kun kan angive meget generelle klicheer om deres kvinder. Den, der observerer godt er den svage, der må kunne udnytte alle små sprækker i harnisket. Det samme har man observeret med homoseksuelle, der ofte identificerer sig mere med de heteroseksuelles skabeloner for homoseksuelle, end heteroseksuelle opfatter det. Det samme gælder kvinders dyd, synonym med kyskhed og trofasthed. Jo højere socialt placeret en mand er (måske med undtagelse af USA), desto mere seksuelt potent fremstår han. Kvinder skal i meget højere grad være trofaste og kyske, efterhånden som de stiger på den sociale rangstige.

Det handler om symbolsk vold som en speciel variant af herredømme. Det er fejlagtigt at tro, at dette sker ved tvang eller begrænsning. Det handler om et pålagt samtykke, der bliver etableret gennem en afpresset anerkendelse, der er resultat af, at den undertrykte kun kan tænke og handle i de termer, selve herredømmeforholdet medgiver; det handler hverken om fysisk tvang eller om frivilligt samtykke.

Maskerede former for undertrykkelse og udbytning, ligesom dem vi studerer her, kunne man kalde for "fornægtede" former i Freuds mening. De maskerer sig ved at låne en del af deres gennemslagskraft fra den logik, der er særegen for slægtsskabsforhold, der fungerer per pligtfølelse forenet med affektiv hengivelse; en type af relation vi genfinder i relationen mellem ægtefæller, mellem den ældste og den yngste søskende, mellem mesteren og slaven, mellem den paternalistiske arbejdsgiver og arbejdstageren.

Disse relationer kan man ikke forklare i økonomiske termer. De reguleres af en anden $\emptyset$ konomi, nemlig økonomien af symbolsk magt, der fungerer uden for al fysisk tvang og efter andre love end den "økonomiske" økonomi. Men man opdager snart, at det symbolske styrkeforholds $\varnothing$ konomi finder sine mulighedsbetingelser og sit modsvar i den $\varnothing$ konomiske $\varnothing$ konomis styrkeforhold. At ud $\varnothing v e$ og opretholde disse symbolske styrkeforhold kræver et intenst arbejde af indprentning, en varig 
forvandling af kroppene, for at opnå de sande og overførbare dispositioner, den symbolske aktion arbejder med.

Al magtudøvelse omfatter en symbolsk dimension: Den må få en accept fra de undertrykte, der ikke beror på en velovervejet beslutning af et oplyst sind, men på den umiddelbare og førbevidste underkastelse af de socialiserede kroppe. Læg mærke til at Bourdieu hele tiden og for første gang i det omfang anvender en hel del psykologisk og psykoanalytisk terminologi, selv en sådan term som socialisation, der tidligere har været bandlyst. Men læg også mærke til, at Bourdieu opretholder en nøje skelnen mellem antropologisk analyse og psykoanalyse, og at de tydelige psykologiske termer, som adopteres, nøje omdefineres, indtil de passer ind i Bourdieus system.

De undertrykte indtænker også undertrykkelsen og dens poler i kategorierne de undertrykte og undertrykkerne, som er lånt fra selve den inkorporerede undertrykkelse. Deres måde at tænke på anvender sig af ikke-gennemtænkte kategorier (ikke-be-tænkte), hvilke er transformationer af basale modstillinger (stor / lille).

Hver gang en undertrykt anvender netop de kategorier (brilliant/anstrengt, distingveret/vulgær, unikt / alment etc.), har han allerede accepteret en måde at tænke på, der i forvejen diskvalificerer ham. I $\varnothing v$ rigt er det forkert at tale om tankekategorier. Det handler egentlig mere om praktiske handlingsskemata, som ligger i en habitus.

\section{Kropsliggørelsen af herredømmeforholdene: somatisering}

Den symbolske vold indgår i alle herredømmeforhold, men udgør det væsentlige i det mandlige herredømme. Det er via habitusbegrebet, at vi kan gøre rede for dens måde at virke på. Men vi må også med det samme stille spørgsmålet: Under hvilke sociale betingelser formes en sådan habitus? Det er nemlig de sociale betingelser, der i sidste ende ligger bagved den gennemslagskraft, som en sådan habitus har, når den træder i aktion, og som bare tilsyneladende virker skæbnebestemt.

Det handler om det arbejde, der former en habitus; man bliver fortrolig med et univers ved, at man udsættes for en kollektiv prægningsproces. Det sker mere implicit end eksplicit, eksempelvis ved at deltage i de store ritualer. Dette arbejde eller den aktion ligner mest dét, man kalder for arbejdsterapi (therapie par la pratique) eller samtaleterapi (therapie par le discours). Den begrænser sig ikke til kun at indprente viden og hukommelser. Når man handler ud fra en habitus, sker det ikke ud fra en mental hukommelse af det billede af en handling, man har indprentet, eller som er bevaret fra ens første erfaring med denne handling. Det handler heller ikke om rent materielle fysiske eller kemiske mekanismer. Det véd vi blandt andet, fordi det har vist sig at være næsten umuligt at lade en robot efterligne de mest banale hverdagsagtige udtryk. Det har vist sig sværere at organisere mekanisk imitation af de mest enkle menneskelige ting end af de mere komplicerede produkter, fordi vi netop ikke har viden om og kontrol over de mest elementære ting. Elementære handlinger er hverken summen af aggregerede reflekser eller produkt af en bevidst kalkyle.

Når man taler om habitussens måde at operere på, skal man holde sig langt borte fra veletablerede akademiske modstillinger såsom teori/praksis, skabe/udføre, intellektuel/manuel, det vil sige i sidste instans modstillingen ædel/vulgær. Det handler ikke om det. Man kan ikke med disse modstillinger og heller ikke med noget, der skulle være midt imellem, karakterisere, hvad det handler om. Selv om skolesystemet hele tiden indprenter netop disse modstillinger $\mathrm{i}$ alle mennesker.

Men dét, der interesserer os specielt her, er spørgsmålet om, hvordan den seksualiserede og seksualiserende habitus virker, under hvilke sociale betingelser den står, og på grund af hvilke sociale betingelser, den har sin gennemslagskraft.

Habitussen producerer de socialt seksualiserede konstruktioner, der udgør verden og ens egen krop. Disse konstruktioner er ikke intellektuelle forestillinger, men aktive principper. De svar 
habitussen udløser i forskellige situationer er ikke produkt af en bevidst kalkyle, der mobiliserer en hukommelse, men heller ikke kemiske mekanismer, der sætter bevidstheden ud af spil. Den sociale verden konstruerer kroppen gennem en konstant dannelsesproces som seksualiseret krop og som krop, der iværksætter seksualiserede iagttagelser og vurderinger af verden og ens egen krop.

Den sociale verden anvender kroppen som sit hukommelsestrick, eksempelvis at slå knude på et lommetørklæde etc. De fundamentale sociale opdelingsprincipper er indskrevne i kroppen som principper for et verdenssyn, et værdisystem eller et system af præferencer, der altid allerede er sat $\mathrm{i}$ værk, inden vi overhovedet aner det.

Det handler om at indskrive en kulturel prægning i kroppen som per definition i en eller anden forstand er i strid med den biologiske natur. Det handler om at samfundsmæssiggøre dyret, at civilisere naturen. Gennem en langsomt opbygget underkastelse af kroppen under de implicitte uudtalte og usigelige tilskyndelser af den sociale orden begynder kroppen at tænke verden og sig selv på sin egen måde, efter sin egen logik. Kroppen tænker sin egen praksis på sin egen måde og på sine egne vegne, milevidt væk fra det, vi i vore platoniske intellektuelle traditioner forstår ved "tænkning". I den tradition har vi en forestilling om refleksion som en virksomhed, der udelukker, at man reflekterer i aktion. Men kroppen gør det.

Den herskende sociale orden oprettes al tid gennem et kup, men dette kup består i langsomt at programmere kroppen på samme måde, som man indprenter et billede i en vokstavle. Dette er den oprindelige betydning på græsk af ordet "karakter" : Det indprentede billede. Dette program fungerer som en anden natur, er princip for perception og vurdering, og er seksualiseret og seksualiserende. Når man søger "en anden natur", mener man den kultiverede natur, der fungerer med samme påtrængende voldsomhed og tilsyneladende blindhed som alle andre socialt konstruerede drifter og fantasmer. Dette socialt konstruerede, men naturaliserede, lagrede program i kroppen opretholder skellet mellem de biologiske $k ø n$ efter de mytiske opdelingsprincipper, der selv er produkt af det vilkårlige mandlige herredømme.

Det er gennem habitussens implicitte arbejde, at de biologiske forskelle mellem mandens og kvindens krop, og specielt de anatomiske forskelle i de seksuelle organer, fremstår som retfærdigg ørelse af de socialt konstruerede kønsroller. I virkeligheden er de biologiske forskelle bare som alt andet til rådighed - inden for visse grænser naturligvis - for snart sagt en hvilken som helst social konstruktion.

I den betydning kan man tale om seksualisme på linje med racisme: Historisk vilkårlig instituerede kønsforskelle tilskrives en biologisk natur, som sidenhen fungerer som et "væsen", ud fra hvilken alle eksistensens handlinger kan udledes.

At råde bod på dette er svært, eftersom det ligger lige for at henvise til det biologiske i dette tilfælde. Socialisering af det biologiske og biologisering af det sociale er lige så gamle fænomener som menneskeheden selv.

En videnskabelig fremstilling af disse forhold er svær, da konstateringen af visse naturaliserede, historiske forskelle som et faktum kan virke som en bekræftelse af netop denne naturalisering. Det forklarer, hvorfor visse forskere går i den modsatte grøft og taler om for eksempel folkekultur, som om den fandtes uafhængigt af den undertrykkelse, den er udsat for, og som forhindrer, at den konstituerer sig netop som folkets kultur.

Habitussen er et produkt af denne indskrivning i kroppen af dominans-forholdet. Habitussen er på én gang en struktureret og en strukturerende struktur, og som sådan er den princippet for en praktisk erkendelse og anerkendelse af den magiske grænse mellem de herskende og de beherskede. På den måde produceres den sociale identitet som totalt indbefattet i denne herredømme-relation.

Det er den erkendelse "per krop" der gør, at de beherskede bidrager til deres egen undertrykkelse gennem en tavs accept, helt uden bevidst stillingtagen eller villet accept af de pålagte 
begrænsninger. De producerer og reproducerer hertil igennem deres egen praksis og med sådanne begrænsninger, som retsordningen allerede har afskaffet.

Derfor kan den, der er offer for denne symbolske vold, heller ikke befries per dekret. Man kan se, at de inkorporerede tvangsmekanismer reproducerer sig især, når de ydre begrænsninger er ophævet, som for eksempel af stemmeret, erhverv, politiske rettigheder, uddannelse eller "kaldet". Selvcensuren tager over fra den ydre begrænsning. Samme mekanisme ser vi, når det gælder de $\varnothing$ konomisk svages forhold til højere uddannelser.

Denne praktiske anerkendelse af undertrykkelsen gør, at grænseoverskridelse er umulig. Overskridelsen er utænkelig. De censurerede adfærdsformer, kvinder opviser, først og fremmest over for mænd og i det offentlige, er ikke påtaget til lejligheden, de er permanente. Og man kan aldrig vide, om de ledsagende subjektive oplevelser af skam, ydmyghed, blufærdighed og angst er årsag eller virkning af disse adfærdsformer. Disse kropslige følelser, der optræder selv udenfor de situationer, hvor de er påkrævede, er former for anerkendelse, der tager de negative fordomme i fork $\varnothing b$. De er former for underkastelse, en måde at opleve kroppens medskyldighed bagom ryggen på én selv og på trods af en indre konflikt og splittelse: Kroppen holder sig væk fra bevidste holdninger, for at alliere sig med de sociale sanktioner.

Habitussens tyngdekraft kan ikke ophæves med vilje ved hjælp af en frigørende bevidsthed. Den, der giver sig hen til sin blufærdighed, er blevet forrådt af sin krop, som allerede har anerkendt forbudet.

Hos kabylerne er kvinder udelukkede fra offentlige pladser. Men selv når sådanne regler er ophævet for længe siden, bærer kvinderne stadigvæk på en slags torveskræk, som er socialt pålagt.

En agents kompetence, der er socialt anerkendt, leder til at agenten også skaffer sig den tilsvarende tekniske kompetence. Dette til forskel fra den kompetence, som agenten har $\mathrm{i}$ overensstemmelse med en officiel, anerkendt ret til at oppebære denne kompetence, som ikke automatisk giver reel mulighed for også at skaffe sig den tekniske kompetence. Derfor er kvinder mindre tilbøjelige til at tilskrive sig selv de kompetencer, de har ret til. Dette forklarer, hvorfor kvinder (mest fra lavere sociale grupper) henviser til deres mand, hvis de bliver interviewet. Hvis de selv svarer, ser de med en vis angst på både den mandlige interviewer og deres egen mand. Det er fysisk besværligt for kvinder at optræde offentligt og frigøre sig fra mandens overopsyn.

Selv når kvinder benytter sig af magiske midler for at underkaste sig manden eller gøre manden enten impotent eller særlig potent, så benægter de, at det drejer sig om at beherske manden, men henviser til specifikke kvindelige behov.

For at formidle herredømmearven til manden (som mand, som ældste, som adelsperson) spiller habitussen en lige så stor rolle. Egentlig drejer det sig om at formidle hans sociale skæbne. Man tror almindeligvis, at det går af sig selv, men det gør det ikke. Disse holdninger er også produkt af et langvarigt socialisationsarbejde. Alt, hvad der tilhører adelsmanden og som manifesterer sig i hans krop, styrer ham kropsligt uden ydre tvang. Det handler om en social identitet forvandlet til skæbne, en skæbne, man forelsker sig i.

Så snart den magiske grænse er draget, loven om de to klasser som objektive størrelser oprettet, så skabes også betingelserne for en vedvarende accept af denne grænse i form af kategorier for perception og vurdering af alt i verden, inklusive ens egen krop og seksualiseringen af den, samt $i$ form af socialt seksualiserede dispositioner. Den vilkårlige lov bliver kun til naturlov, hvis dens kropsliggørelse (somatiseringen) er fuldbyrdet.

Kønnet er altså produkt af et socialt konstruktionsarbejde, af en psykosomatisk aktion, der frembringer de mest overfladiske adfærdsformer lige så vel som de dybeste impulser fra det ubevidste, sådan som psykoanalysen har beskrevet dem.

Det bliver helt tydeligt, når man studerer de mandlige initiationsriter, der i klar tekst iscenesætter dét, der sidenhen fremstår som den mandlige fetichisme. Derfor må disse riter ikke betragtes som 
initiationsriter eller overgangsriter mellem dét, der var før, og dét, der er efter, men som institutionsriter, der én gang for alle instituerer den ene gruppe og udelukker den anden gruppe, placerer dem, der hører til, over for dem, der ikke hører til. Institution er opfattet i dobbelt betydning som en fast ordning (for eksempel ægteskabet) og en udpegning (for eksempel af en arvtager).

Den mandlige og den kvindelige krop samt deres seksualorgan er socialt konstruerede ud fra habitussen. De bliver symbolske bærere af alle de betydninger og værdier, der passer til det phallokratiske syn på verden. Det er ikke phallossen, der skaber dette syn. Det er dette syn, konstrueret af sociale grunde, der endnu er tilbage at klarlægge, som instituerer phallossen som princip for kønsopdelingen i overensstemmelse med opdelingen af verden i relationelle størrelser (over/under, mandlig/kvindelig). Sådan skabes de sociale forskelle og underordningen i form af væsensforskelle, der har en "objektiv" forankring i de naturlige, biologiske forskelle.

Manden kommer først både i den seksuelle adfærd, der er legitim, og i den seksuelt baserede sociale arbejdsdeling: Han er ovenpå. Dermed er modellen lagt for alle perceptioner, vurderinger og handlinger for samfundsmedlemmerne. Den udgør en uomtvistelig forankring, upåvirkelig af bevidstgørelse og unders $\varnothing$ gelse. Det er ikke den biologiske reproduktions nødvendigheder, der bestemmer den seksuelle arbejdsdeling, men en vilkårlig strukturering af det biologiske, som giver det mandlige syn på verden et skin af naturlighed. Det syn opererer med en dobbelt styrke: Det legitimerer et herredømme ved at skrive sig ind i kroppen, selv om det er en forkropsliggjort, social konstruktion.

Det er via æreskoden, at kabylerne tillægger den mandlige virilitet forrang. Til og med den etiske side af koden hænger sammen med fysiske forhold (retten til at deflorere, betydningen af et stort antal børn). Phallossen bliver bæreren af alle de sociale fantasmer, der associeres med den befrugtende magt.

Den befrugtende magt symboliseres i den opsvulmede phallos og i madvarer, der svulmer op, hvilket hører til ægteskabsfesten eller til pløjningsriterne om foråret hos kabylerne. Samme symbolik vender tilbage i Lacans sprog. Penis og bryst, sperma og mælk, testikel og æg bliver til forskellige sider af den fundamentale mandlige evne til at få tingene til at svulme op og blive frugtbare.

Kollektive forestillinger (som Emile Durkheim angav som det sociale) er ikke selvstændige størrelser, men sociale konstruktioner, der tillægger biologien, såsom penis's evne til at blive stiv, betydningen af at være bærer af frugtbarheden. Den sociale konstruktion bekræfter det biologiske grundlag. På denne måde kan vi overskride to ensidige tilgange til disse problemer: En idealistisk konstruktivisme, der kun tager meningen fra et idésæt, og den objektivistiske realisme, der finder betydningen parat $\mathrm{i}$ tingene. Den kulturelle selektion af betydningsladede træk, der tillægges betydning, indoptager naturlige egenskaber og forekommer derfor ikke kulturelt selektiv, men naturlig.

En anden forstærkningsmekanisme er, at modstillingen mandligt/kvindeligt indlejres i en lang række universelle modstillinger: Fuld/tom, over/under osv. Kosmiske og biologiske forhold bliver på denne måde helliget. Bedstefar genopstår i sin sønnesøn, der bærer hans navn, på samme måde som kornet genopstår. En social konstruktion indoptager en analogi med naturlige forhold og ophøjer begge dele til dele af en hellig natur.

Men selv om der er et nært slægtsskab mellem de naturlige forhold og de sociale kulturelle konstruktioner, så er der altid plads til kognitive diskrepanser. Dette tillader de undertrykte at tage revanche ved at benytte symbolikkens relative ubestemthed og vende den mod deres undertrykkere i samme øjeblik, de er offer for den. Kvinden i Kabylien siger til sin mand: "Alt det, du har, hænger kun nedad, mens mit er som to sten, der er vokset sammen": Hun bruger præcis samme mekanisme og samme symbolik (slap/fast), men vender den mod manden i forsvarsøjemed. Man skal ikke glemme, at netop i kampen mod kvinderne opretholdes mandens herred $ø$ mme. Grundlaget for kampen er givet i det mandlige syn på verden og dets mekanismer, som det uomgængelige sociale og 
semantiske felt for striden. Modstanden er der, men det er en del af feltet, ikke en afkræftelse af grundlaget for striden.

Med en vis reservation i sit begrænsede materiale mener Bourdieu, at kvindens $k \varnothing n$ i dette mandlige syn i princippet er negativt defineret, dvs. som manglen på det mandlige. Bourdieu illustrerer dette med et citat fra Jean-Paul Sartres L'Étre et le néant. Her beskrives kvindens køn som et klæbrigt hul, det eksisterer alene "i sig" til forskel fra det, der eksisterer som bevidsthed, det vil sige "for sig" (en soi/pour soi); et typisk eksempel på definitionen af kvindekønnet som negativitet.

Andre eksempler er tekster fra middelalderens lægebøger, der taler om det kvindelige kønsorgan som en indadvendt penis, eller hele den moderne mytologi om betydningen af kvindens clitoris i den seksuelle oplevelse helt frem til Freud og hans kritikere. Om noget gør, så viser den "story", at det handler om sociale konstruktioner over biologien.

Kroppen er et semantisk felt af betydninger, den har en $\emptyset$ vre del, der er ren og en nedre del, der er uren, med navlen som .grænse. En forreste del, der er seksualiseret og en bagdel, der ikke er det, det vil sige som er kvindelig eller homoseksuel i middelhavskulturer. Kombinationen konstituerer de ikke-skamfulde dele, der er til for at præsentere og repræsentere offentligt (ansigtet, øjnene, skæg, munden), og de skamfulde dele, der er private og skal tilsıres.

I forlængelse af den symbolik er manden den, der tager til orde offentligt, mens kvinden tier i alle offentlige sammenhænge. På denne måde institueres den grundlæggende kombination af "phallos" og "logos", af mandlighed og rationalitet.

Men Bourdieu viser også, hvordan samlejet - som social kulturel størrelse i ord og handling - i Kabylien er opbygget efter det mandlige herredømme med det selvfølgelige som kernepunkt, at manden skal være "ovenpå" i alle ordets betydninger. Kvindeligt og mandligt initiativ på det punkt kontrasteres i myten åbent og direkte som natur og kultur.

Det samme ligger på en mere underforstået måde og derfor mere effektivt $\mathrm{i}$ alle mandlige institutionsritualer, der har omskærelsen som sin kerne: Det afgørende i denne potensering af mandligheden er, at den bekræfter, at noget sådant overhovedet ikke kommer kvinden ved. Bourdieu betragter disse riter som separationsriter, dvs. riter, der afskærer drengen og manden fra alt det kvindelige, også i sig selv, og til at begynde med fra sin mor. Det handler om et stadigt og uophørligt psykosomatisk viriliseringsarbejde og feminiseringsarbejde, der er socialt reguleret. Eftersom seksualitet ikke bare er seksualitet, men det hele, findes der ikke plads til individuel improvisation. Vi véd fra alle antropologiske studier, at graden af offentlig ritualisering af et domæne er proportionalt med dets betydning for det sociale liv. Det handler om en dannelsesproces, der forvandler barnets mangeartede perversitet til mandlighed/kvindelighed for at sige det med Freud, der sikkert ikke var klar over i hvilken grad han med begrebet perversitet (og netop fordi han ikke mente det som en moralsk kategori) bekræfter det phallokratiske livssyn, han selv tænker i.

Derfor er den grundlæggende socialisering, der danner kroppen som seksualiseret krop, en politisk socialisering: Den instituerer og kropsliggør et herred ømmeforhold. Den kropsliggjorte habitus genererer derefter alle tanker og handlinger. Kulturens kropsliggørelse konstruerer det ubevidste.

\section{Illusionen og den sociale genese af lysten til at herske}

Kvinder lærer sig de negative dyder som selvfornægtelse, opgivenhed og tavshed via det socialiseringsarbejde, de udsættes for. Men mændene er også fanget i og på en lumsk måde offer for den fremherskende forestilling samtidig med, at den passer deres interesser. Dette mytisk-rituelle system fungerer som selvforherligelse, når det bare én gang er institueret i de objektive sociale strukturer og i de subjektive mentale strukturer, der organiserer perception, vurdering og handling. 
Der findes ikke længere plads til en afkræftelse (dementi). Ophøjelsen af de mandlige værdier har sit modstykke i angsten for det kvindelige, der giver ophav til mistænksomhed.

Kvinden repræsenterer hos kabylerne den mandlige æres sårbare side, hun er venstresiden af det hellige, altid åben for krænkelse. Men hun er også altid muligheden for en djævelsk list: Den svages våben mod den stærke, bedrageri og magi stillet over for styrken og retten. Kvinden er muligheden for vanære og ulykke. Mandens privilegium betales altså med prisen af en stadig spænding og strid. Behovet for at befæste sin mandlighed kan tage absurde former, som for eksempel $\mathrm{i}$ anvendelsen af midler for at forhøje potensen i det uendelige, hvilket modsvares af kvindernes snakken om mændenes potens.

Mandens privilegium (hans private lex, specielle lov) er en fælde. At være mand er i sig selv ikke bare at have ret til en masse, som man er alene om at have ret til, men det er også at være forpligtet til en masse, som man er alene om. Når man for eksempel udelukker kvinderne fra alt det offentlige, betyder det også, at man udelukker, at de nogensinde tilegner sig dét, der kræves for at bevæge sig offentligt, hvilket igen betyder, at man ikke kan forlange noget som helst af kvinderne i den henseende.

Når en social kultur ubevidst gennemgår den grundlæggende fordeling mellem mænd og kvinder efter denne herred ømme-model, henvises mænd alene til at klare alle sociale spil, der tages alvorligt, og de socialiseres til at tilegne sig de dispositioner, der kræves for at spille dette spil alvorligt. På denne måde bliver manden offer for en illusion, det vil sige han giver sig ind i spillet. Det handler om et spil, en kulturel, vilkårlig model for den sociale orden, hvor mandens herredømme udelukker kvinden. At tage spillet alvorligt er en illusion og derfor en måde at deltage i spillet på, der tager spillet for givet. Alt dette gør, at manden opfatter sin pligt til at være en mand af ære som pligten til at være et menneske i det hele taget.

Mænd er bestemt til kampen om akkumulationen af den symobolske kapital, det vil sige til kampen mellem mænd. Kvinder er bestemt til at være udelukkede fra denne kamp eller til at være formål for den som objekt og bytte i mændenes kamp om (den største) ære. Det, man må forstå er, at et og samme grundlæggende ordningsprincip (mændenes herredømme) stifter en social orden, der udelukker kvinderne fra den sociale kamp mellem mændene om myndigheden, og udleverer mændene til den kamp. Det handler ikke om en kamp mellem mænd og kvinder, men om en kamp mellem mænd, der udelukker kvinderne.

På det punkt, som på så mange andre, skulle man kunne nuancere Bourdieus analyse, der primært baserer sig på de islamiske kabylere og sekundært på hele middelhavsområdets kultur, fra antikken til i dag, ved at betragte det sorte Afrikas naturreligion og stammekultur. Det sorte Afrikas segmentære samfund er også karakteriseret af samme mandsherredømme uden om kvinderne, og uden om de unge mænd. Men dette går hånd i hånd med en systematisk opretholdelse af den principielle lighed mellem alle ældre mænd og sætter dermed klare grænser for kampen om akkumulation af symbolske goder.

Kort sagt: Den herskende er behersket af sit herredømme, hvilket dog er noget helt andet end at være behersket af en anden. Dette er en side af sagen, der ofte overses af feminismen, men som har fundet et lysende udtryk i Virginia Woolfs romaner. Man skal snarere læse hendes To the Lighthouse (Woolf, 1977a) end hendes feministiske romaner A Room of Ones Own (Woolf, 1970) eller Three Guineas (Woolf, 1977b). Gennem selve skrivearbejdet som kvindelig forfatter har hun interesseret sig særligt for anamnesen, det analyserende tilbageblik, der skal forklare, hvorfor en kvindelig forfatter skriver, som hun gør. Hun opdager aspekter, der er forblevet skjulte for hendes mandlige kolleger, der er "hypnotiserede af deres herredømme", som hun siger. I romanen beskriver hun forholdet mellem de to køn på en måde, der er befriet for alle de gængse forhold mellem de to køn, befriet for alle de gængse klicheer om seksualitet, penge, kultur og magt. Hun beskriver kvindens syn på 
mandens desperate anstrengelse for at kunne leve op til sin egen infantile idé om manden, patetisk i sin triumferende ubevidsthed.

Familien Ramsay er på ferie på en $\emptyset$, og fru Ramsay har lovet sin 6-årige søn en udflugt til et fyr den næste dag. Hr. Ramsay stiller sig på tværs ved at sige, at det bliver dårligt vejr i morgen.

ÆEgtefællerne strides om sagen. Der bliver ingen udflugt. Senere dør hustruen, og manden må tage udflugten alene med sin $s \varnothing n$.

Woolf lader hustruen være den, som på et tidligt stadium indser, at hendes mand, der for omgivelserne optræder som en mægtig mand og faderfigur, i virkeligheden vikler sig mere og mere ind i sin egen barnlighed. Han optræder som hellige konger i arkaiske samfund: Deres ord er lov, deres dekret skaber og tilintetg $\varnothing$ r virkeligheden, eftersom de repræsenterer Gud selv. På denne måde tilintetgør han sønnens ønske og glæde med det enkle udsagn: "Det bliver dårligt vejr i morgen". Hans prognose går i opfyldelse som en befaling eller som magiske besværgelser, der er blevet virkeliggjort. Han udsiger det, som bare han, den seende, kan vide om fremtiden, som spåmanden. Han er i stand til at fordoble naturens og samfundet love gennem sin klarsynede udtalelse, som forvandler disse love til rationelle indsigter og empiriske fakta. Faderens profeti fungerer som et påbud, der konstaterer sin egen virkeliggørelse. Dét, der var en mulig fremtid, begrænses af den alvidende erfaring, der påbyder den totale konformisme. Faderen repræsenterer uforkortet virkelighedsprincippet (i Freuds betydning) i modsætning til moderen, som repræsenterer begæret og lysten, men kompletteret af den kvindelige underkastelse under det mandlige realitetsprincip. Moderens: "Såfremt vejret bliver godt" tilintetgøres af faderens: "Det bliver dårligt vejr i morgen". Faderens fuldkommen vilkårlige måde er glædesforstyrrende, idet den tager en glædesl $\varnothing s$ verdensorden i fork $\varnothing$ bet i realismens og rationalitetens navn og fremkalder s $\emptyset$ nnens had. Drengen reagerer ikke så meget mod naturens nødvendighed, som mod faderens ureflekterede bekræftelse af denne nødvendighed ("alt tyder på at det bliver dårligt vejr ..."). I dette afslører faderen sin svaghed: Han kommer i forkøbet og har den tvivlsomme glæde at berøve andre deres illusioner og tvinge dem til at dele sin resignation.

Fædrenes ord mod deres sønner udformer sig spontant som besværgende eller forebyggende forudsigelser, der bebuder fremtiden som en trussel, men også udgør en umiddelbar trussel: "Du må holde op med at være vred", og når det viser sig, at dette virker som en selvopfyldende profeti, kan faderen bagefter triumfere og derigennem kompensere for smerten over ikke at være blevet modsagt i virkeligheden: "Jeg havde håbet, du skulle gøre mig til en løgner".

Barnets mest radikale revolte retter sig ikke mod faderen, men mod dets egen spontane, men indlærte, tendens til at adlyde faderen.

Derimod holder moderen, inden for rammerne af sin underkastelse vel at mærke, sagen og sit engagement åben: "Det kan jo blive fint vejr - og jeg tror, at det bliver det".

Woolf beskriver også scenen set fra faderens synspunkt, som han må se sig selv, hvis han skal være det syn på sig selv værdigt, som systemet pålægger ham.

Han må jo sige sandheden, den bistre sandhed, uforkortet, uden at give efter selv for sine nærmeste: Livet er svært, man kan ikke indgå kompromiser med fakta, det er nytteløst at have illusioner. Han taler ikke ud fra den egoistiske lyst til at berøve andre deres illusioner, han vælger bevidst at handle korrekt ud fra en velovervejet faderkærlighed, der ikke viger for moderkærlighedens eftergivelser og blindhed. Woolf udtrykker det med billedet af sværdet, som kapper den oprindelige illusion om fusionen med moderen/naturen og stopper alle fors $\emptyset \mathrm{g}$ på at hengive sig til sine impulser. Man begynder at ane, at også bødlen selv er offer, at faderens ord, netop på grund af deres magt fremkalder den skæbne, den vil afværge.

Som kontrast beskriver Woolf i samme roman faderens barnlige fantasier om, hvordan han optræder under en krig ("Han ser sig selv $\mathrm{d} \varnothing$ oprejst") eller hans angstfulde fantasier om den store filosof: "Måske ét eneste menneske af en hel generation kan opnå en sådan højde. Kan man laste 
nogen for ikke at være netop det menneske?" Til og med helten kan jo spørge, hvor længe man husker på hans heltedåd.

Woolf lader altså faderen på et fantastisk plan beholde alle de illusioner, han forbinder med sin rationalitet og realisme. Samtidig med at han er tvunget til at indse, at han i hvert fald ikke er en helt, så køber han gennem indrømmelse af ikke at være en helt retten til at se sin realisme i heltemodige dage: Han bevarer sin overbevisning om, at spillet er indsatsen værd, at man skal spille spillet efter reglerne og til den bitre ende.

Den mandlige hengivelse til lysten til at beherske er en illusion, det vil sige en måde at deltage $\mathrm{i}$ spillet på, som om det ikke var et spil. Illusionen ytrer sig siden på alle mulige planer hos alle mænd, til forskel fra kvinderne.

Mænd deltager uden forbehold i alle spil, de socialt bliver pålagt at spille, med krigen som den fuldkomne form for spil. Af alle de sociale spil er de, der betragtes som alvorlige, også dem, der er forbeholdt mænd. Det vil sige, de spil det lykkes at få til at fremstå som nødvendige. Kvinder og børn overlades netop til barnagtigheder. På denne måde glemmer mændene, at de selv er børn, som spiller mænd.

\section{De udelukkedes klarsynethed}

Kvindens negative privilegium er, at de ikke er duperet af de spil, hvor man kæmper om privilegierne, og at de ikke lader sig gribe af denne ego-fiksering. Kvinden kan indse spillets tomhed og med lun overbærenhed være tilskuer til mandens-barnets desperate fors $\emptyset \mathrm{g}$ på at være mand, så længe hun ikke er engageret i disse spil, men som ombud, gennem mellemmand. Hun kan være observat $\varnothing$ r på afstand og bliver derfor ofte betragtet som letsindig og ukyndig ved alvorlige lejligheder, som for eksempel i politik. Men hendes distance er en effekt af at være underlagt et herredømme. For det meste er kvinden dømt til at deltage i manden-barnets alvorlige lege per mellemmand, nemlig ved at vise sin affektive solidaritet med manden-spilleren (ikke med spillet, som de står intellektuelt og affektivt udenfor), Det gør, at kvinderne ofte er dårligst informerede om spillet, men de mest betingelsesløse tilhængere af deres mænd.

Fru Ramsay indser umiddelbart, at hendes mand ikke har tænkt sig om, når han afslører sine fantasier om at være krigshelt for sine gæster. Hun er på hans vegne bange for den smerte, bevidstheden om at være afsløret vil fremkalde, men også for smerten, når han opdager, at han bare bilder sig alt muligt ind.

På samme måde lader Woolf kvinden kærtegne sønnens hoved som trøst for faderens forstyrrende indgreb, men i en kortslutning bliver det også en kærtegning af hendes mand-barn for at trøste ham for tabet af illusionen. Med en gestus, som hele hendes placering i det mytiske-rituelle herred $\varnothing$ mme-system mellem mænd og kvinder har bevirket, tager hun de svage, sønnen og den fader, han hader, under sin affektuøse beskyttelse.

For at respektere sin mands værdighed afslører fruen ikke sit klarsyn, men hun ved udmærket, at han også selv er offer for den dom, han har afsagt over sin søn. På samme måde som sønnen fortjener han medlidenhed. Med mindre man tror, at hun bliver offer for mandens sidste list, nemlig at han sikrer sig kvindens moderlige følelser af medlidenhed ved at være som et barn.

Woolf lader ægtefællerne føre en dialog, hvor begge hele tiden ved, at store afgrunde åbner sig for dem hver især ved hvert relativt banale stridspunkt, såsom udflugten og det, der bliver sagt om den. Begge investerer det minimum af medskyldighed og ond tro i samtalen, som gør det muligt at udkæmpe en konflikt med hinanden om alt i en samtale, der blot handler om ingenting.

Hver samtalepartner lader den anden beholde chancen for i hvert øjeblik at lade som om, at han/hun ikke (længere) forstår, hvad det er, man taler om, ved pludselig at tale om det banale, som 
det umiddelbart handler om (i dette tilfælde morgendagens vejr). Eller i samme øjeblik fortsætte samtalen med den totale indforståethed og forståelse, der er den tavse forudsætning for både konflikten og for en eventuel forsoning. Det handler om et spil mellem alt og intet, hvor begge dele hele tiden er mulige, den totale misforståelse omkring morgendagens vejrlig og/eller den totale konflikt/forsoning omkring livet og mandens/kvindens skæbne.

Fru Ramsay véd, hvor hendes mands svage punkt ligger: Behovet for at være helt, når man $\mathrm{i}$ virkeligheden er som et barn. Derfor ved hun, at manden ikke tåler den mindste bemærkning, som sætter spørgsmål ved hans heltemod. Helten/barnet tåler ikke denne konfrontation med sin sårbarhed.

Hvor har fru Ramsay sit klarsyn fra? Eftersom hun selv står helt uden for det mandlige spil og den obsessionelle ophøjelse af sit eget jeg og alle de sociale impulser, der følger af det, ser hun, at de mest absolutte holdninger til den sociale, alvorlige virkelighed kun er en måde at føre sig selv frem på.

Virginia Woolf markerer klart den fremmedgørelse, der ligger i herred $\varnothing$ mmer: Manden g $\varnothing r$ karriere ved at iscenesætte sig selv som patriot for Gud og fædrelandet og bliver siden tvunget til resten af sine dage at tro på Gud og fædrelandet. De er indskrevet på hans halsbånd, som hundens navn på dens halsbånd er det, siger Woolf. At kvinderne eksplicit og systematisk bliver udelukket fra mændenes spil og indbyrdes kamp og udsættes for segregering eller apartheid udgør baggrunden for deres klarsynethed. De ser gang på gang en bror forvandles til et hankøns-monster, som tordner løs, og til et barn, som med kridt tegner mystiske grænselinjer mellem mennesker på gulvet. Han tegner de cirkler, inden for hvilke han, beklædt med guld og purpur, dekoreret med fjer som en høvding, er i gang med sine mytiske riter og nyder sine mistænkelige lyster, mens kvinden sidder hjemme, låst inde uden at måtte deltage i nogle af de selskaber/foreninger, der udgør samfundet.

Men hvis kvinden er fri for at deltage i dette spil i egen person, så er hun sjældent fri for at deltage i sin mands deltagelse. Da er ikke spillet, men netop manden i fokus. Hun deltager per mellemmand, ud fra en position, der er uden for spillet og underkastet spilleren. Hun deltager på mandens eller sønnens præmisser. Den position giver også tryghed.

Dette resultat af den sociale kønsopdeling registrerer allerede Immanuel Kant, når han - som om han konstaterede en naturens orden - siger, at kvinden ikke kan forsvare sig hverken inden for domstolen eller i krig, undtagen gennem en advokat. Derimod hersker hun i husholdningen, men kun med den svages ret til at være beskyttet af den stærke.

Slutproduktet af hele denne proces er ikke bare en habitus. Den opfører sig som en social institueret bøjelse (libido), som den specielle libido, vi kalder begæret. Den kønsdifferentierede socialisering prædisponerer manden til at elske de sociale spil og kvinden til at elske manden, som spiller disse spil. Disse dispositioner er politiske dispositioner, og derfor er også seksuelle forhold magtforhold, fordi det handler om sociale ordninger indskrevet i kroppen. At have magt er forførende, i hvert fald for dem, der er prædisponeret til at blive forført af det. Cirklen slutter totalt, hvis den undertrykte kvinde elsker sin undertrykkelse via en forelskelse i undertrykkerens charme.

Både Kant og Woolf er klar over, at den kvindelige position også har sine fordele: Hun er fri for at deltage i kampen, og hun nyder godt af den tryghed, som den store beskytter giver. Dette ophæver aldrig angsten, da hun véd, at den store beskytter er et sårbart barn, og da hun aldrig selv kan gå ind på scenen, når det begynder at gå galt. Kvinden må da beskytte sin mand mod alle fadermord; hun selv har ingen anden dækning i ryggen end ham.

Som Franz Kafka har vist det, har faderens ord en konstituerende magisk virkning; ordet udvirker dét, ordet nævner, fordi faderens ord taler direkte til kroppen. Og kroppen, som Freud har vist det, tager metaforer bogstaveligt ("Du er et lille kryb"). Fordelingen af den sociale libido, det vil sige begæret efter at deltage i de sociale spil, fremstår som forbavsende vel tilpasset de pladser i spillet, enhver har fået tildelt efter køn, alder og en mængde andre kriterier. Denne harmoni beror på, at 
fordelingen sættes i værk af faderen. For selv om det ser ud som om, faderen går efter sine tilfældige lyster og bestemmer ting og sager helt vilkårligt, skal man huske på, at faderen selv er formet af livets

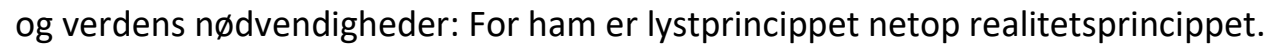

\section{Kvinden som objekt}

Den mandlige habitus konstrueres og virkeliggøres inden for det reserverede rum af alvorlige sociale lege og kappestride mellem mænd alene. Her kan begæret om at herske udfolde sig i alle sociale felter: Økonomi, politik, religion, kunst, videnskab og krig.

Kvinderne er udelukkede og har rollen som tilskuere, der på fordelagtig måde spejler spillerne. Kvinderne tilbagekaster en forstørret spejling af det billede, manden har af sig selv, og som han skal leve op til. Kvinderne forstærker derigennem mandens narcissistiske besættelse af sit eget idealbillede.

Eftersom kvindens underkastelse tager den form, så fungerer den ved at rette sig mod manden som unik person med sine indfald og sin krop.

Underkastelsen udformer sig som behag, karisma, frihed og giver manden en anerkendelse, som ingen anden kan give ham, som retfærdigg ør hans eksistens. Viriliseringen, mandliggørelsen af manden, kan på trods af, at den udspiller sig i en egen sfære, endnu ikke rigtigt komme i stand uden kvindens meddelagtighed. Den har brug for kvindernes måde at tilbyde sig, at tilbyde sin krop på: Kvinden giver sig hen til manden, som man siger.

Endnu er grundloven for alle sociale spil, at der er et udbytte mellem lige, det vil sige mellem mænd. Æren, der ligger i udfordringen eller $i$ at tage en udfordring op, kan manden kun få af en anden mand, og af en mand af ære. Kvinderne er bogstaveligt talt sat ud af spillet.

Naturligvis er den fordeling i dag i mange henseender sat ud af spil, blandt andet fordi kønssegregeringen er ophævet i skolen, til og med inden for de højere uddannelser, og på visse måder i erhvervslivet. Billedet af kvinden som husmor er fjernet. De feministiske kampe har også bidraget til dette, først og fremmest ved at sætte rollefordelingen mellem kønnene på dagsordenen, dér hvor den egentlig hører hjemme, nemlig som et politisk spørgsmål i oprindelig forstand: Et spørgsmål om den grundlæggende magtudøvelse i samfundet. Ikke desto mindre eksisterer den gamle ordning videre i en mængde sociale praktikker og ubevidste dispositioner.

Den magiske grænse, Woolf taler om, lader grænsen mellem mand og kvinde falde sammen med grænsen mellem kultur og natur, mellem det offentlige og det private, og giver manden monopol på det universelt menneskelige. Kvinden kan ikke være subjekt i de afgørende sociale spil. Forskellen bliver i bund og grund til en forskel mellem subjekt og objekt, mellem agent og instrument, en forskel der er et opdelingsprincip for universet som helhed og for alle symbolske ordninger.

Forholdet mellem mand og kvinde er bare et særligt tilfælde af den generelle husholdning med symbolske goder, der først og fremmest kommer til udtryk i slægtskabssystemet. Dér får kvinderne overalt på jorden rollen af at være bytteobjekt i overensstemmelse med mandens interesser, både som døtre og som søstre. De er materiale for reproduktionen af mandens symbolske kapital. Alle de kulturelle systemer, der giver mandlighed forrang, bygger på denne husholdning. Incestforbudet er i henhold til Claude Lévi-Strauss samfundets indstiftelseshandling, for så vidt den pålægger udbyttet af kvinderne mellem mænd med kvinderne som objekt. Den symbolske vold, med hvilken kvinderne bliver reduceret fra subjekter til objekter for udbytte og alliancer, er mere grundlæggende end forbudet mod incest, hvilket bare er en konsekvens.

Den symbolske vold kan man se i de arkaiske ceremonier, der har at gøre med navngivningen, men også i ægteskabet, hvor kønsforskellen markeres, og kvinden til og med får et andet navn. 
Derfor bliver mandens herredømme også mest udtalt i de samfund, hvor den eneste akkumulation af kapital, som er mulig og tilladt, er akkumulationen af symbolsk kapital. Her er kvinderne ikke bare symboler, men symboler som er kapital, som man må bevare uantastet, og som må stilles over enhver mistanke, Det handler om en social kapital gennem alliancer, der bygger på en symbolsk kapital: Den pletfri ære. Når ikke bare ægtemanden, men også fædre og brødre til kvinden er fuldstændig paranoidt jaloux med hensyn til kvinden, så er dette ikke andet end en velgennemtænkt magtinteresse: Det handler ikke om kvindens ære, men om kvinden som mandens ære.

Dér ligger måske også forklaringen på, hvorfor denne grundmodel i den grad har kunnet overleve alle ændringer i produktionsformerne, selv den industrielle revolution, fordi reproduktionen af den symbolske kapital har en relativ autonom logik. De store borgerlige familier er vedvarende afhængige af deres sociale og symbolske kapital for at reproducere deres rendyrkede $\varnothing$ konomiske kapital og fortsætter således med at opretholde mange træk fra den arkaiske model.

Det mandlige syn på verden sætter også sit præg på måden at holde hus med den rent biologiske reproduktion. Kvindens biologiske privilegium at føde og opforstre børn bliver symbolsk nulstillet til fordel for mandens rolle som den, der befrugter kvinden! Det er det mandlige indgreb, der regnes, ved samlejet og pløjningen, og ikke svangerskabet eller udsædens modning i jorden. I alle livets aktiviteter er det de korte, pludselige, voldsomme aktiviteter, der regnes og bliver fejret, mens de velkendte, opremsende, monotone aktiviteter sker i det skjulte. Når man siger som Mary O'Brian, at det mandlige herredømme er en overkompensering for mandens bristende kontrol over instrumenterne for den biologiske reproduktion, så må man tilføje, at herredømmet bare er en del af den mere grundlæggende kontrol over den symbolske reproduktions instrument.

Kvindernes rolle i det reproduktive arbejde (at $f ø$ de børn og at varetage husholdningen) er langt op i vore dage socialt og symbolsk irrelevant, men økonomisk nødvendigt. Dette kom helt tydeligt frem, da kvinderne opdagede, at ordningen blev brudt, da de kom ud i erhvervslivet. Og selv da fik kvinderne det reproduktive som tillæg til deres nye produktive rolle.

Gennem hele 1900-tallet formulerer fortalerne for kvindernes indtræden på arbejdsmarkedet en diskurs, hvor kvindernes produktive rolle fornægtes og erstattes med en idealisering af den som bærere af åndelighed, moral og følelser, også i erhvervslivet.

Så snart kvinder selv stiller krav, som mænd i tusinde år har betragtet som deres naturlige rettighed, begynder hele samfundet og naturligvis mændene at stille spørgsmål til disse kravs berettigelse, eller i det mindste relativere dem med ironisk eftergivenhed: "Nå, ja, egentlig er det ingenting at have, men hvis I nu absolut vil ... I kommer nok til at opdage, at det ikke er morsomt ... ".

Fornægtelsen af kvindernes rolle i produktionen og reproduktionen er altid proportional med højtideligg ørelsen af den rolle, som mændene ønsker at se dem i. Hvis kvinderne lader det syn stå uimodsagt, så forbliver de først og fremmest cirkulationsobjekt på et symbolsk marked med kosmetik og modetøj som de mest synlige symboler. Kvinder og kvindernes arbejde hører det kosmetiske til.

De bliver behandlet og ser også sig selv som objekt for æstetisk vurdering, social værdsættelse osv. Den side af livet er de ansvarlige for ikke bare hos sig selv, men også hos deres mænd, børn, hus osv. Selv om de er minearbejdere, skal de sørge for, at der ikke bare findes kartofler, men også blomster i den lille have. Desuden står kvinderne for alle ceremonier og fester.

De forestår kort sagt forvaltningen af familiens symbolske kapital, ikke dens produktion og reproduktion. De står for "kulturen".

Alle disse egenskaber finder vi maksimeret hos kvinderne i det moderne småborgerskab, der til forskel fra overklassen er totalt underkastet modellen og følger den med højeste iver. Småborgerskabets kvinder er tillige dem, der videregiver modellen til de lavere sociale klasser. På kredit skaffer man sig flest mulige dekorative statussymboler. 
Det er sjældent, at disse kvinder opdager, at de ikke har en chance for at fors $\varnothing$ ge at leve op til deres rolle, og at deres eneste chance ligger $\mathrm{i}$ at vælte den ordning, det hele bygger på.

\section{En institutionel libido}

En afsløring af det mandlige herredømme som kultur og orden kan let fremstå, først og fremmest for ordenens herre, som en partisk anklage, og for ofrene som en bekræftelse på en orden. Den enkelte kan fremstille forholdene ikke bare som fakta, men som normer. Videnskabelig kundskab om

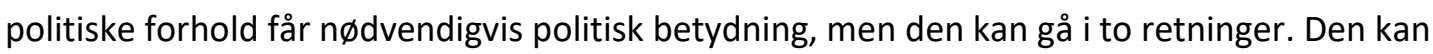
anvendes som en slags efterrationalisering af det herskende, eller den kan lægge hindringer i vejen for herred $\varnothing$ mmet og st $\varnothing$ tte en kritisk bevidsthed og ofrenes mobilisering.

På samme måde sagde man i sin tid, at skolen fungerer konservativt for at åbne op for muligheden af, at skolen kan fungere frigørende. I dag må man vise kvinderne det, den sociale ordning har gjort dem til, og hvordan de selv bidrager til deres undertrykkelse.

Der er en st $\varnothing r r e$ fare for, at forskeren låner sit undersøgelsesobjekt fra førvidenskabelige forhold, $\mathrm{i}$ det her tilfælde "kvindesagen", idet engagementet da kommer til at erstatte konstruktionen af det videnskabelige objekt. Derfor har vi fået populistiske studier af de folkelige klasser, sorte studier af de sorte, homofile studier af homoseksuelle og feministiske studier af kvinder. Faren ved disse studier er, at forskerne på grund af deres engagement i den gode sag ikke mener, at de behøver at gøre rede for deres grundlag og derfor ikke reflekterer alle positive følelser og i $\varnothing$ vrigt legitime interesser. Faren er også, at ofrene tror, de har monopol på erfaring med området og eneret på kundskaben, hvilket kan spærre dem inde i en ghetto.

Feministerne gør "opdagelser", som gennem lang tid har tilhørt socialvidenskabernes arv, eksempelvis opdagelsen af kønsforskelle som naturaliserede kulturprodukter. Det er ikke meningsfyldt i den utopiske fordomsfriheds navn at udelukke den individuelle og kollektive motivation, der leder til et intellektuelt og politisk engagement. Men man må være klar over, at en politisk motivering giver dårlig videnskab og på længere sigt dårlig politik, hvis man ikke kan forvandle sine impulser til kritik, udsprunget af sit eget engagement.

Afsløringen kan dog i det her tilfælde være mere effektiv end ellers, eftersom det fundamentalt set handler om en symbolsk vold. Det vil sige et herredømme, der bygger på miskendelse af de virkelige forhold og som ikke tåler at fremstå i al sin banalitet. Man skal dog huske på, at denne symbolske vold ikke bare er en sag for bevidstheden, men for kroppen, og at kroppen ikke samstemmer med bevidstheden. Det er ikke let at bryde kæden af ubevidste læreprocesser, der går fra krop til krop mellem generationerne. Kun en symbolsk kamp, der medfører et praktisk spørgsmål, kan bryde den quasi-naturvidenskabelige overensstemmelse mellem inkorporerede strukturer $\mathrm{i}$ sindet og objektiverende strukturer i den sociale virkelighed på en måde, der kommer alle ved, undertrykkere og undertrykte.

Det er den viriliserede mands skæbne, at hans begær udformer sig som et begær om at herske over andre mænd. Og dertil benytter han sig af kvinderne som instrument. Manden kan ikke indtræde på det sociale spils scene uden at være ledt af begæret for at spille og vinde, sådan som spillet er tilrettelagt. Dette institutionelle begær fungerer som et over-jeg, der leder til de mest ekstreme former for egoisme såvel som til de mest ekstreme former for selvforsagelse, eksempelvis at $\mathrm{d} \varnothing$ for fædrelandet: Krig har altid været dette sociale spils højeste form, dets paradigme.

I og med at kvinderne er udelukkede fra dette spil, har de haft let ved at genkende sig selv i visdomstraditioner, der har prædiket forsagelse. Men denne ansats til kritisk klarsynethed har for det meste ingen chance mod den pålagte identifikation med alle mandesager gennem tiderne. 
Kvindernes krig mod krigen er en utopi. Måden at opfatte livet selv som identisk med at herske er uhyre sårbart for omstyrtende virksomhed.

Man kan næppe overvurdere, hvad det ville betyde, hvis grundprincipperne for det mandlige

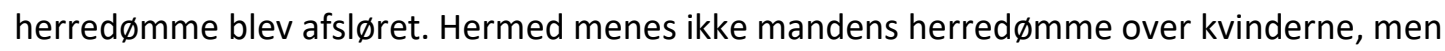
mandens måde at identificere livet med herredømme over andre mænd med udelukkelse af kvinderne.

Sammenhængen bliver tydelig, når vi ser, hvordan ultramandschauvinisme går hånd-i-hånd med politisk despoti. Social harme ladet med politisk vold søger næsten altid sin næring i både sociale og seksuelle fantasmer i den politiske racisme og i de anklager for pornokrati, som despotien møder parlamentariske regimer med. Men man kan ikke forvente, at den kollektive bevidstgørelse vil resultere i en forandring af de mentale dispositioner og de tilsvarende sociale strukturer, så længe kvinderne indtager de positioner i produktionen og reproduktionen, som de gør.

Disse positioner er det virkelige fundament for deres status i det symbolske system. En forudsætning for en sådan forandring er en generobring af alle mekanismer af socialt herredømme. Disse mekanismer forhindrer, at man i det hele taget kan se kulturen som noget andet end en måde at skille sig ud på, at udmærke sig i forhold til naturen, der ikke er andet end et naturaliseret socialt forhold. Så længe kulturen er identisk med mandens måde at markere sig over for andre mænd og udelukke kvinder på; identisk med den ene fraktion af overklassens måde at markere sig på over for andre fraktioner af overklassen, idet man udelukker arbejdere og bønder; identisk med de hvides måde at udelukke de sorte på, de heteroseksuelles måde at udelukke de homoseksuelle på - så længe forbliver herredømme definitionen på selve livet.

Kulturen, som i sig selv kun er en instituering af menneskeligheden ved hjælp af forsagelse og sublimering, bliver da mere og andet end sublimering, den bliver vilkårligt herredømme. Så længe disse mekanismer er fremherskende, kommer kvinder, fattige, etniske minoriteter, kolonialt undertrykte til at være brændemærkede, stigmatiserede. Selv om kvinderne i dag ikke længere overalt og i lige stor udstrækning udgør det afsæt mod hvilket løberen i de sociale spil sætter af, så er de fortsat med i spillet mere som objekt end som subjekt. Underforstået: At være subjekt for netop disse spil, præcis som mænd, er ikke en rigtig sejr, og i henhold til Bourdieu tydeligvis heller ikke fuldt ud muligt, så længe begge $k \varnothing n$ og hele den sociale ordning følger kampens love.

Kvindernes undertrykkelse er ikke en selvstændig størrelse, men en total social ordning. Den er bagsiden af mændenes kampordning og kan ikke ophæves, undtagen hvis helheden ophæves.

Det er ganske bemærkelsesværdigt, at Bourdieu i sidste instans, efter at have analyseret det specifikke og det kulturelle i denne undertrykkelse, med så stort eftertryk vender tilbage til og genindfører kulturens og kønsfordelingens fundament under et globalt, sociologisk perspektiv, der mest er beslægtet med Karl Marx' samfundsanalyse.

\section{Referencer}

Bourdieu, P (1990). La Domination Masculine. Actes de la recherche en sciences sociales, 84, Paris s. 2-31.

Callewaert et al. (Red.)(1994-2008). Pierre Bourdieu. Centrale tekster inden for sociologi og kulturteori. 1.-4. oplag København: Akademisk Forlag 1994-1998, 5. oplag København: Frydenlund 2008, s. 20-48.

Woolf, V. (1977a). To the Lighthouse. London: Penguin.

Woolf, V. (1977b). Three Guineas. 6. oplag, London: Hogarth.

Woolf, V. (1970). A Room of ones own. London: Penguin. 
ourdieu \& Passeron, 1970) er velkendt her, hvilket får bestemte kommentatorer - og visse af dem har ikke tøvet med det - til at klassificere mig som strukturalist, mens arbejder, som stammer fra en meget tidligere periode, er ukendte. De er så gamle, at de oven i købet foregriber de typisk 'konstruktivistiske' arbejder om de samme emner. Disse arbejder ville uden tvivl gøre, at jeg ville blive opfattet som 'konstruktivist': Således viste vi i en bog kaldet Rapport pédagogique et communication (Bourdieu, Passeron, de Saint Martin red., 1965), hvordan en social erkendelsesrelation konstrueres i og ved misforståelse, eller på trods af misforståelse; hvordan lærere og studenter efter en art tavs forhandling, tavst ledet af behovet for at minimere omkostninger og risici, bliver enige om at acceptere en minimal definition af kommunikations-situationen. På samme måde fors $\varnothing$ ger vi i en anden unders $\varnothing$ gelse kaldet "The Categories of Professorial Judgement" (Bourdieu, 1988) at analysere genesen og funktionen af de opfattelses- og vurderingskategorier, gennem hvilke lærere opfatter deres elever, deres præstationer og værdi, og ved hjælp af selvsupplering, vejledt af de samme kategorier, producerer deres egen gruppe, nemlig den, der består af deres kolleger og derved lærerkollegiet. Nu, da denne korte parentes er af vejen, kan jeg vende tilbage til mit overordnede emne).

Taler man i meget generelle termer, svinger socialvidenskaben, i antropologi såvel som i sociologi og historie, mellem to tilsyneladende uforenelige synspunkter, to tilsyneladende modstridende perspektiver: Objektivisme og subjektivisme, eller hvis man foretrækker det, fysikalisme og psykologisme (som kan tones forskelligt, fænomenologisk, semiologisk etc.). På den ene side kan socialvidenskab "behandle sociale fænomener som ting", i overensstemmelse med den gamle durkheimske maksime, og således udelade alt det, der tilskrives det faktum, at de er objekter for erkendelse - eller miskendelse - med social eksistens. På den anden side kan socialvidenskab reducere den sociale verden til den repræsentation, agenterne skaber af den, således at socialvidenskabens opgave er at producere et "resultat af resultaterne" produceret af sociale subjekter.

Det er sjældent at disse to positioner udtrykkes, og endnu mere at de realiseres i videnskabelig praksis, på så radikal og kontrasterende en måde. I ved, at Émile Durkheim uden tvivl, sammen med Karl Marx, er den person som har udtrykt den objektivistiske position mest konsistent: "Vi mener, at ideen om, at det sociale liv skal forklares, ikke ud fra agenternes tanker, men af de dybe årsager, der ligger uden for bevidstheden, er frugtbar." Men som en god kantianer var han ikke uvidende om, at denne virkelighed ikke kan begribes uden at bringe logiske instrumenter i arbejde. Når dette er sagt: Objektivistisk fysikalisme associeres ofte med den positivistiske hang til at forestille sig klassifikationer som 'operative' måder at skære ting op eller som mekaniske registreringer af 'objektive' brud og diskontinuiteter (f.eks. i statistiske fordelinger). Det er uden tvivl hos Alfred Schutz og etnometodologerne, at man kan finde de reneste udtryk for den subjektivistiske vision. Således indtager Schutz nøjagtig det modsatte standpunkt af Durkheims:

Socialvidenskabsmandens observationsfelt, den sociale virkelighed, har en særlig mening og passende struktur, relevant for de mennesker, som lever, handler og tænker i den. Ved en serie af sund fornuftkonstruktioner har de forud valgt og oversat den verden, som de opfatter som deres dagliglivs virkelighed. Det er disse tankeobjekter, som determinerer deres adfærd ved at motivere den. Tankeobjekterne, konstrueret af socialvidenskabsmanden med det formål at begribe denne sociale virkelighed, skal baseres på de tankeobjekter, som er konstrueret af sund fornufts-tænkningen af de mennesker, som lever deres daglige liv i deres sociale verden. Således er socialvidenskabernes konstruktioner, så at sige, andengrads konstruktioner, dvs., konstruktioner af konstruktionerne, udført af aktørerne på den sociale scene (Schutz, 1973).

Modsætningen er total: I det ene tilfælde kan videnskabelig viden udelukkende opnås ved at bryde væk fra de primære repræsentationer - kaldet forudantagelser hos Durkheim og ideologi hos Marx; 
dette brud fører til antagelsen af ubevidste årsager. I det andet tilfælde ligger videnskabelig viden i forlængelse af sund-fornufts viden, fordi det kun er en "konstruktion af konstruktioner".

Hvis det virker, som om jeg har arbejdet lidt vel rigeligt med denne modsætning, et af de mest uheldige af de begrebspar, der, som Reinhard Bendix og Bennett M. Berger har vist det, florerer i de sociale videnskaber, er det fordi den mest konstante, og i mine øjne den vigtigste, intention med mit arbejde har været at overskride modsætningen. Med fare for at virke meget uklar vil jeg forsøge at opsummere hele den analyse jeg sigter mod i dag, i en sætning: På den ene side: De objektive strukturer, som sociologen konstruerer ved at tilsidesætte agenternes subjektive repræsentationer $\mathrm{i}$ det objektivistiske moment; de er basis for de subjektive repræsentationer, og de konstituerer den strukturelle tvang som påvirker interaktioner. Men på den anden side: Disse repræsentationer skal også huskes, når man fremfor alt vil tage højde for de daglige individuelle og kollektive kampe, der har til formål at forandre eller bevare disse strukturer. Dette betyder, at de to momenter, det objektivistiske og det subjektivistiske, står i et dialektisk forhold, og selvom f.eks. det subjektivistiske, hvis det tages isoleret, synes meget tæt på interaktionistiske eller etnometodologiske analyser, er det adskilt fra dem med en radikal forskel: Udgangspunkterne opfattes som sådan og relateres til positionerne i de korresponderende agenters struktur.

For fuldt ud at overskride den kunstige modsætning, der tenderer mod at opstå mellem strukturerne og repræsentationer, må man også bryde med den tankemåde, som Ernst Cassirer kalder substantialistisk, og som forleder folk til ikke at anerkende nogen virkeligheder udover dem, der er tilgængelige for direkte intuition i almindelig erfaring, hos individer og grupper. Det største bidrag til det, man må kalde den strukturalistiske revolution, bestod i at tilføje den sociale verden en relationel tankemåde, som er den samme som i moderne fysik og matematik, og som identificerer det virkelige ikke med substanser, men med relationer. Den "sociale virkelighed", som Durkheim talte om, er et sæt af usynlige relationer, de selvsamme relationer som konstituerer et rum af positioner, udvendige i forhold til hinanden og defineret ved deres nærhed til, naboskab med eller afstand fra hinanden, og også ved deres relative position - over eller under, eller endog imellem, $\mathrm{i}$ midten. Sociologi, i dets objektivistiske moment, er en social topologi, en analysis situs, som denne nye gren af matematikken blev kaldt på Gottfried W. Leibniz' tid, en analyse af relative positioner og objektive relationer mellem disse positioner.

Denne relationelle tænkemåde er udgangspunktet for konstruktionen, som er præsenteret i $L a$ Distinction. Men det er rimeligt at mene, at rummet, dvs. relationerne, vil være ubemærkede af læserne, på trods af brugen af diagrammer (og af korrespondanceanalysen, som er en meget sofistikeret form for faktoranalyse): På den ene side fordi den substantialistiske tænkemåde er lettere, mere 'naturlig'; på den anden side fordi, som det ofte er tilfældet, de midler, man er nødt til at benytte for at konstruere det sociale rum og for at kunne manifestere dette, risikerer at skjule de resultater, midlerne gør én i stand til at opnå. De grupper, man skal konstruere for at kunne objektivere de positioner de optager, skjuler disse positioner, og kapitlet i La Distinction om fraktioner af den dominante klasse læses som en beskrivelse af disse fraktioners forskellige livsstile, $i$ stedet for at blive læst som en analyse af måden, hvorpå de skal ses som positioner i rummet af magtpositioner - det som jeg kalder magtfeltet. (I parentes vil jeg bemærke, at ændringen i ordvalg, som I kan se, både er betingelsen for og resultatet af at bryde med de ordinære repræsentationer, som er associeret med ideen om en herskende klasse.)

Man kan på dette sted i diskussionen sammenligne det sociale rum med et geografisk rum, som er delt op i regioner. Men dette rum er konstrueret således, at agenterne, grupperne eller institutionerne, som finder sig selv situeret i det, har flere egenskaber til fælles, desto tættere de er på hinanden i dette rum; og færre fælles egenskaber desto fjernere de er fra hinanden. Rumlige afstande - på papir - falder sammen med sociale afstande. Det samme er ikke tilfældet i et virkeligt rum: Det er sandt, at man næsten overalt kan observere en tendens til isolation; folk, der er tæt på 
hinanden i det sociale rum tenderer - af valg eller nødvendighed - mod at være tæt på hinanden i det geografiske rum; imidlertid kan folk, som er meget fjerne fra hinanden i det sociale rum støde på hinanden, påvirke hinanden, i det mindste kortvarigt og forbigående, i det fysiske rum. Interaktioner, der tages for pålydende af folk med en empiricistisk disposition - idet man kan observere dem, filme dem, registrere dem, kort sagt de er håndgribelige - skjuler de strukturer, som realiseres i dem. Det er et af de tilfælde, hvor det synlige, det som er umiddelbart givet, skjuler det usynlige, som determinerer det. Man glemmer derfor, at interaktionens sandhed aldrig fuldstændigt kan findes tilgængelig i interaktionen, som den er tilgængelig for observation. Ét eksempel er tilstrækkeligt. til at vise forskellen mellem struktur og interaktion og, på samme tid, mellem den strukturalistiske vision, som jeg vil forsvare som et nødvendigt forsknings-moment, og den såkaldte interaktionist-vision i alle dens udtryksformer (i særdeleshed etnometodologi). Jeg tænker på det, som jeg kalder strategierne for at nedlade sig. Agenter, der optager en højere position i et af det objektive rums hierarkier, benægter symbolsk den sociale distance. Den ophører hermed ikke med at eksistere, men de højtstillede håber det sikrer dem de anerkendelsens fordele, som er knyttet til en rent symbolsk benægtelse af distance ("han er upåvirket", "han gør sig ikke til" etc.). Den symbolske benægtelse implicerer imidlertid en anerkendelse af en distance (de sætninger jeg har citeret har altid implicit en fortsættelse: "Han er upåvirket, af at være hertug", "han gør sig ikke til af at være universitetsprofessor" etc.). Kort sagt, man kan bruge de objektive distancer til at opnå fordelene ved nærhed og fordelene ved distance, dvs. den distance og den anerkendelse af distance, som er sikret ved den symbolske negation af distance.

Hvordan kan man således konkret begribe disse objektive relationer, som ikke kan reduceres til de interaktioner inden for hvilke de manifesteres? Disse objektive relationer er relationer mellem positionerne, som er besat i fordelingen af ressourcer, som er eller vil blive aktive, effektive, som trumferne i et spil kort, i konkurrencen om tilegnelsen af de sjældne goder, som dette sociale univers er locus for. I overensstemmelse med mine empiriske unders $\emptyset$ gelser er disse fundamentale sociale kræfter, økonomisk kapital i dens forskellige former, kulturel kapital og også symbolsk kapital, som er en form, der antages af forskellige slags kapital, hvis de opfattes og anerkendes som legitime. Derfor er agenterne fordelt i det totale sociale rum, i den første dimension i overensstemmelse med det totale omfang af den kapital de besidder i forskellige former, i den anden dimension $i$ overensstemmelse med strukturen af deres kapital, dvs. i overensstemmelse med den relative vægt de forskellige slags kapitaler, økonomiske og kulturelle, har af den totale kapital.

De misforståede læsninger af analyserne, som jeg har udført især i La Distinction, stammer derfor fra det faktum, at klasser på papir risikerer at blive opfattet som reale grupper. Denne realistiske læsning bliver objektivt understøttet af det faktum, at det sociale rum er konstrueret på en sådan måde, at agenter, som optager samme eller lignende positioner, er placeret i ensartede forhold og underkastet ensartede betingelser, og har alle chancer for at have ensartede dispositioner og interesser, og således for at producere praktikker som endda er ensartede. De dispositioner, som er opnået i de besatte positioner, implicerer en tilpasning til denne position, som Erving Goffmann kaldte for "fornemmelsen for ens placering". Det er denne fornemmelse for ens placering, som får folk - på fransk kaldet 'les gens modestes', dvs. 'almindelige mennesker' - til i interaktioner at holde sig til deres 'almindelige' sted og de andre til at 'holde afstand' eller 'respektere deres rang' og 'ikke blive fortrolige'. Disse strategier kan imidlertid være helt ubevidste og kan antage former som generthed eller arrogance. Faktisk er sociale afstande indskrevet i kroppene eller, mere præcist, $\mathrm{i}$ forholdene til kroppen, til sprog og til tid. (Dette er så mange af de strukturelle aspekter af praktikken, som ignoreres af den subjektivistiske vision).

Hvis man til dette lægger, at fornemmelsen for ens placering, og habitus' affiniteter erfaret som sympati eller antipati, er grundlag for alle former for samarbejde, venskaber, kærlighedsaffærer, giftermål, forbindelser etc., altså for alle de forhold, som er langvarige og somme tider sanktioneret 
ved lov, så vil man se, at alt fører én til at tro, at klasser på papir er reale grupper - endog mere reale, eftersom rummet er bedre konstrueret, og enhederne, i hvilke dette rum er underinddelt, er mindre. Hvis man vil grundlægge en politisk bevægelse eller ligefrem en forening, vil man have en bedre chance for at bringe folk sammen som befinder sig i den samme sektor af rummet (f.eks. i det nordvestlige af diagrammet, der hvor de intellektuelle er) end hvis man vil bringe de folk sammen, som er i regionerne i de fire hjørner af diagrammet.

Men ligesom subjektivismen får folk til at reducere strukturer til interaktioner, tenderer objektivismen mod at udlede aktion og interaktion fra strukturen. Så hovedfejlen, fejlen ved teoretiseringen, som man finder hos Marx, ser ud til at bestå i at behandle klasser på papir som reale klasser ved at konkludere fra betingelsers og påvirkningers objektive homogenitet og således fra dispositioner, som alle stammer fra identiteten af positionen i det sociale rum, til at de involverede mennesker eksisterer som en forenet gruppe, som en klasse. Opfattelsen af socialt rum tillader en at gå bagom alternativet nominalisme eller realisme, når det kommer til sociale klasser: Det politiske foretagende, som havde til hensigt at producere sociale klasser som 'samarbejdende enheder ', permanente grupper, udrustet med permanerfre repræsentationsorganer, forkortelser etc., har så meget desto st $\varnothing$ rre chance for succes, fordi de agenter, som det $\emptyset$ nsker at bringe sammen, forene og konstituere som en gruppe, er tættere i det sociale rum (og tilhører således den samme klasse på papiret). Klasser i Marx' forståelse skal produceres af et politisk foretagende, som har så meget desto st $\varnothing$ rre chance for succes, i og med at det understøttes af en teori, som er velfunderet i virkeligheden, og som derfor er i stand til at udføre en teorieffekt - theorein på græsk betyder at se - der med andre ord er i stand til at påtvinge en vision om opdelingen.

Med teorieffekten har vi forladt den rene fysikalisme, men uden at opgive den erfaring, som er opnået i den objektivistiske fase: Grupper - sociale klasser - skal skabes. De er ikke givet i den "sociale virkelighed". Titlen på den berømte bog af E. P. Thompson, The Making af the English Working Class (Thompson, 1963), skal tages bogstaveligt: Arbejderklassen, som den fremstår for os i dag, via de ord som skal betegne den (arbejderklasse, proletariat, arbejdere, arbejderbevægelser etc.), og med de organisationer, som skal udtrykke den (de forkortede navne, kontorerne, sekretariaterne og flagene etc.), er en velfunderet historisk artefakt (forstået sådan som Durkheim formulerede det: At religionen er en velfunderet illusion). Men det betyder ikke, at man blot kan konstruere hvad som helst, på hvilken som helst måde, hverken i teorien eller i praksis. Vi har således bevæget os fra social fysik til social fænomenologi. Den "sociale virkelighed", som objektivisterne taler om, er derpå et objekt for perception. Socialvidenskaben må nødvendigvis som sit objekt tage både denne virkelighed og opfattelsen af denne virkelighed, perspektiverne, synspunkterne, som agenterne har om denne virkelighed, i kraft af deres position i det objektive sociale rum. De spontane visioner om den sociale verden ("folketeorierne", som etnometodologerne taler om, eller det, jeg kalder spontan sociologi), men også videnskabelige teorier og sociologien er dele af den sociale virkelighed og kan, som f.eks. den marxistiske teori, opnå en i det hele taget virkelig, konstruerende magt.

Det objektivistiske brud med forudopfattelser, ideologier, spontan sociologi, og "folketeorier", er et uundgåeligt og nødvendigt moment i den videnskabelige procedure. Man kan ikke undgå det uden at udsætte sig selv for alvorlige fejltagelser (som interaktionisme, etnometodologi og alle former for socialpsykologi, der stiller sig tilfredse med en fænomenologisk vision om den sociale verden). Men man må udføre et andet og mere vanskeligt brud med objektivismen ved, i et andet trin, at reintroducere det, det var nødvendigt at udelukke for at konstruere den sociale virkelighed.

Sociologi skal indeholde en sociologi om opfattelsen af den sociale verden, dvs. en sociologi om konstruktionen af de verdenssyn, som selv bidrager til konstruktionen af denne verden. Men givet det faktum, at vi har konstrueret et socialt rum, ved vi, at disse synspunkter, som det ligger i ordet selv, er syn, der går fra et bestemt punkt, dvs. fra en given position inden for det sociale rum. Vi ved også, at der vil være forskellige eller ligefrem modsatte synspunkter, fordi synspunkter er afhængige 
af fra hvilket punkt der ses. Den vision, enhver agent har om rummet, er afhængig af hans eller hendes position i det pågældende rum.

Ved at gøre dette, nægter vi at anerkende det universelle subjekt, fænomenologiens transcendentale ego, som etnometodologerne har overtaget som deres eget. Agenterne har uden tvivl en aktiv forståelse af verden. Uden tvivl konstruerer de deres vision om verden. Men denne konstruktion udføres under strukturel tvang. I sociologiske termer kan man ovenikøbet forklare, hvad der forekommer som en universel egenskab ved menneskelig erfaring, men som i den velkendte verden tenderer mod at blive 'taget for givet', opfattet som naturlig. Hvis den sociale verden tenderer mod at blive opfattet som indlysende og som begribelig med en doxisk modalitet, for at bruge Edmund Husserls termer, er det fordi agenternes dispositioner, deres habitus, dvs. de mentale strukturer, gennem hvilke de forstår den sociale verden, essentielt er produktet af en internalisering af strukturerne i den sociale verden. Ligesom dispositioner i forbindelse med opfattelse af omgivelserne tenderer mod at blive tilpasset til positionen, vil selv de mest forfordelte agenter tendere mod at opfatte verden som naturlig og at finde den meget mere acceptabel end man skulle forestille sig, især hvis man ser de domineredes situation med de dominerendes sociale øjne.

At lede efter de invariante former for perception eller konstruktionen af social virkelighed tilslører altså forskellige ting: For det første det faktum, at denne konstruktion ikke udføres i et socialt vakuum, men at den er underkastet strukturel tvang; for det andet, at de strukturerende strukturer, de kognitive strukturer, selv er socialt struktureret, fordi de er af social oprindelse; for det tredje, konstruktionen af social virkelighed er ikke kun en individuel opgave, men kan også blive en kollektiv opgave. Men den såkaldt mikro-sociologiske vision udelader en hel del andre ting: Som det ofte sker, når man ser nærmere efter, kan man ikke se skoven for bare træer; og fremfor alt, fordi man ikke har konstrueret rummet, har man ingen chance for at se det punkt, hvorfra man kan se, hvad man ser.

Derfor varierer agenternes repræsentation med deres position (og de tilhørende interesser) og med deres habitus, som et system af opfattelses- og vurderings-modeller, som kognitive og evalueringsmæssige strukturer, der er opnået gennem en langvarig erfaring med en social position. Habitus er på samme tid et system af modeller til produktion af praktikker og et system af modeller til opfattelse og vurdering af praktikker. I begge tilfælde udtrykker dens operationer den sociale position, i hvilken den er konstrueret. Som et resultat producerer habitus praktikker og repræsentationer, som er tilgængelige for klassifikation, som er objektivt differentierede; men umiddelbart opfattes de som sådanne udelukkende i det tilfælde, hvor agenterne besidder koden, de klassifikatoriske modeller, som er nødvendige for at forstå deres sociale mening. På denne måde implicerer habitus en 'fornemmelse for ens egen placering' men også en 'fornemmelse for den andens placering'. Vi siger for eksempel om et stykke tøj, et møbel eller en bog: 'Den er småborgerlig' eller' den er intellektuel'. Hvad er de sociale betingelser for en sådan bedømmelse? For det første forudsætter den, at smag (eller habitus), som et system af klassifikatoriske modeller, objektivt, gennem de sociale betingelser som producerede den, henviser til et socialt vilkår: Agenterne klassificerer sig selv, udsætter sig selv for klassifikation, ved, i overensstemmelse med deres smag, at vælge forskellige attributter, tøj, typer af mad, drikke, sportsgrene, venner, som går godt sammen og som de også synes de stemmer overens med, eller mere præcist, som de synes er passende for deres position. Mere præcist: De klassificerer sig selv i rummet med tilgængelige varer og tjenesteydelser ved at vælge ting, som optager en plads i dette rum overensstemmende med positionen, de optager $\mathrm{i}$ det sociale rum. Det betyder, at intet klassificerer nogen bedre end den måde, hvorpå han eller hun klassificerer.

For det andet forudsætter en klassifikatorisk bedømmelse, såsom 'det er småborgerligt', at vi som socialiserede agenter er i stand til at se relationen mellem praktikker eller repræsentationer og positioner i det sociale rum (som når vi kan gætte en persons sociale position ud fra hans eller 
hendes accent). På denne måde har vi, via habitus, en verden af sund fornuft, en social verden, som synes at være indlysende.

Jeg har indtil nu antaget det opfattende subjekts position og har nævnt den vigtigste faktor $\mathrm{i}$ variationerne af opfattelse, nemlig positionen i det sociale rum. Men hvad med variationer, hvis oprindelse snarere er på objektets niveau, på selve dette rums niveau? Det er sandt, at den overensstemmelse, der gennem habitus, disposition og smag etableres mellem positioner og praktikker, demonstrerede præferencer, udtrykte holdninger etc., betyder, at den sociale verden ikke præsenterer sig som totalt kaos, fuldstændig blottet for $n \varnothing$ dvendighed og i stand til at blive konstrueret på hvilken som helst måde. Men denne verden præsenterer heller ikke sig selv som fuldstændigt struktureret, eller som værende i stand til at påtvinge ethvert opfattende subjekt principperne for sin egen konstruktion. Den sociale verden kan beskrives og konstrueres på forskellige måder i overensstemmelse med forskellige principper for vision og division - for eksempel $\emptyset$ konomiske inddelinger og etniske inddelinger. Hvis det er sandt, at $\varnothing$ konomiske og kulturelle faktorer har størst indflydelse på differentieringen i de samfund, som er mest avancerede ud fra et $\varnothing$ konomisk synspunkt, er det faktum tilbage, at styrken af $\varnothing$ konomiske og sociale forskelle aldrig er således, at man ikke kan organisere agenterne ved hjælp af andre inddelingsprincipper - f.eks. etniske, religiøse eller nationale.

På trods af denne potentielle mangfoldighed af mulige struktureringer - hvad Max Weber kaldte die Vielseitigkeit af det givne - er det ikke desto mindre sandt, at den sociale verden selv præsenterer sig som en stærkt struktureret virkelighed. Det er på grund af en simpel mekanisme, som jeg hurtigt vil skitsere. Det sociale rum, som jeg har beskrevet det ovenfor, præsenterer sig som agenter udstyret med forskellige egenskaber, der er systematisk sammenkædet: De mennesker, der drikker champagne, er modstillet dem, der drikker whisky, men de er også på en anden måde modstillet dem, der drikker rødvin; men de, der drikker champagne, er mere tilbøjelige end dem, der drikker whisky, og meget mere tilbøjelige end dem, der drikker rødvin, til at have antikke møbler, spille golf, ride eller til at gå $\mathrm{i}$ teatret for at se lette komedier. Disse egenskaber fungerer som tegn i det sociale livs virkelighed, når de opfattes af agenter udstyret med relevante opfattelseskategorier (i stand til at se, at det at spille golf får en til at 'ligne' et traditionelt medlem af den $\varnothing v r e$ middelklasse): Forskellene fungerer enten positivt eller negativt som skelsættende tegn og som tegn på skel, og dette sker uden nogen intention om denne skelnen, uden noget ønske om iøjnefaldende forbrug. Det skal i $\varnothing$ vrigt siges, at mine analyser intet tilfælles har med Oswald Veblens: Dette er så meget desto mere sandt, som at skelnen, set ud fra oprindelige kriterier, udelukker ethvert ønske om skelnen. Med andre ord præsenterer den sociale verden sig objektivt via den fordeling af egenskaber som et symbolsk system, der er organiseret i overensstemmelse med logikken om forskel, om differentieret variation. Det sociale rum tenderer mod at fungere som et symbolsk rum, et rum med livsstile og statusgrupper, karakteriseret ved forskellige livsstile.

På denne måde er opfattelsen af den sociale verden et produkt af en dobbelt strukturering: På det objektive niveau er den socialt struktureret, fordi egenskaberne knyttet til agenterne eller institutionerne præsenterer sig selv i kombinationer, som har meget ulige sandsynligheder: Ligesom det er mere almindeligt, at fjerede dyr har vinger end at pelsede dyr har det, er indehaverne af en sofistikeret bemestring af sprog mere sandsynlige på et museum end dem, der ikke har denne bemestring. På det subjektive niveau er opfattelsen af den sociale verden struktureret, fordi de opfattelses- og evalueringsmæssige modeller, især de nedskrevne, udtrykker tilstanden for den symbolske magts relationer. Jeg tænker eksempelvis på de adjektivpar (tung/let, strålende/dunkel etc.), som strukturerer smag på de mest forskellige domæner. Disse to mekanismer handler sammen for at producere en fælles verden, en verden af sund fornuft eller, i det mindste, en minimumsenighed om den sociale verden. 
Men som jeg har foreslået det, kan objekterne i den sociale verden opfattes og udtrykkes på forskellige måder, fordi de altid inkluderer en grad af ubestemthed og uklarhed og dermed en vis grad af semantisk elasticitet: Kombinationer af de mest konstante egenskaber er altid baseret på statistiske sammenhænge mellem udskiftelige karakteristika; og ydermere er de underkastet variationer over tid, så deres mening, for så vidt som de er afhængige af fremtiden, selv er holdt i uvished og relativt ubestemte. Dette objektive element af usikkerhed - som ofte er forstærket af kategoriseringseffekten, idet det samme ord kan dække forskellige praktikker - tilbyder et grundlag for en mangfoldighed af verdenssyn, som selv er kædet sammen med en mangfoldighed af synspunkter. På samme tid tilbyder det objektive element et grundlag for symbolske kampe om magten til at producere og påtvinge en vision om den legitime verden. (Det er i midterpositionerne i det sociale rum, især i De forenede Stater, at ubestemtheden og den objektive usikkerhed om forholdene mellem praktikker og positioner er på deres højeste; og som en konsekvens er også intensiteten af kampen mellem de symbolske strategier skruet op. Det er let at forstå, at det er dette univers som udgør interaktionisternes priviligerede terræn, og især Goffmans.)

Symbolske kampe om opfattelsen af den sociale verden kan antage to forskellige former. På det objektive plan kan man pege på repræsentations-handlinger, individuelle eller kollektive, beregnet til at afsı øre og vigte sig af bestemte realiteter. Kollektivt tænker jeg for eksempel på demonstrationer, hvis formål er at pointere en gruppe, dens størrelse, dens styrke, dens sammenhængskraft, at synliggøre dens eksistens; og på det individuelle plan tænker jeg på alle selv-præsentationsstrategierne, som er så velanalyserede af Goffman, designet til at manipulere ens selvopfattelse og især - hvad Goffman udelod - opfattelsen af ens position i det sociale rum. På det subjektive plan må man handle ved at fors $\varnothing$ ge at ændre opfattelses- og evalueringskategorierne i den sociale verden, de kognitive og evalueringsmæssige strukturer. Opfattelseskategorierne, klassifikationssystemerne, det vil hovedsageligt sige ordene, navnene, der konstruerer den sociale virkelighed lige så meget, som de udtrykker den, er den afgørende indsats i den politiske kamp. Den politiske kamp er en kamp for at påtvinge de legitime principper for vision og division - ergo en kamp for den legitime udøvelse af teorieffekten. Jeg har vist med tilfældet Kabylien, at grupper, husholdninger, klaner, stammer og navnene, der betegner dem, er instrumenter og objekter for utallige strategier, og at agenterne uafladeligt er beskæftiget med forhandlinger om deres egen identitet: For eksempel kan de manipulere med stamtavler ligesom vi, og af andre årsager, manipulerer med lærebøgerne af de fædre, som har grundlagt disciplinen. På niveau med den daglige klassekamp, som de sociale agenter gennemfører i en isoleret og splittet tilstand, er strategierne ligeledes fornærmelser, såsom magiske fors $\varnothing \mathrm{g}$ på kategorisering: Sladder, rygter, bagvaskelser, insinuationer, etc. På det kollektive og mere egentligt politiske niveau inkluderer de alle strategierne, som sigter mod at påtvinge en ny konstruktion af den sociale virkelighed ved at afvise det gamle politiske ordforråd, men ellers sigter mod at opretholde det ortodokse syn ved at bevare de ord, som oftest er eufemismer (lige nu refererede jeg til udtrykket 'almindelige mennesker'), udformet til at beskrive den sociale verden. De mest typiske af disse konstruktionsstrategier er dem, der sigter mod retrospektivt at rekonstruere en fortid, tilpasset til nutidens behov - som da general Flemming, da han landede i Frankrig i 1917, sagde: "La Fayette, here we come!" - men ellers sigter mod at konstruere fremtiden, gennem en kreativ forudsigelse, bestemt til at begrænse den evigt-åbne betydning af nutiden.

Disse symbolske kampe, både de individuelle dagligdags kampe og de kollektive, organiserede kampe i det politiske liv, har en specifik logik, som sikrer dem en reel autonomi fra de strukturer, i hvilke de har rod. I kraft af det faktum, at den symbolske kapital ikke er andet end økonomisk eller kulturel kapital, som dog er erkendt og anerkendt, idet den ses i overensstemmelse med de opfattelseskategorier, den selv påtvinger, tenderer den symbolske kapital mod at reproducere og forstærke de magtrelationer, som konstituerer strukturen i det sociale rum. Mere konkret: Legitimeringen af den sociale orden er ikke, som bestemte folk tror, et produkt af en velovervejet 
forudindtaget propagandaaktion eller symbolsk påtvingning; den skyldes det faktum, at agenter tilføjer den sociale verdens objektive strukturer opfattelses- og vurderingsstrukturer, som er opstået af disse objektive strukturer og derfor vil forstå verden som selv-indlysende.

Objektive magtrelationer tenderer mod at reproducere sig i symbolske magtrelationer. I den symbolske kamp om produktionen af sund fornuft eller, mere præcist, om monopolet for legitim navngivning sætter agenter den symbolske kapital, som de har opnået i tidligere kampe og som juridisk kan garanteres, i kraft. På denne måde repræsenterer adelstitler, ligesom uddannelsesmæssige kvalifikationer, reelle titler med symbolsk egenskab, som giver én retten til fordelene ved anerkendelsen. Også her bliver man nødt til at flytte sig fra marginalistisk subjektivisme: Den symbolske orden er ikke konstitueret som en markedspris ved den blotte mekaniske addition af de individuelle ordener. På den ene side har ikke alle bedømmelser den samme vægt ved fastsættelsen af den objektive klassifikation og hierarkiet af værdier tildelt individer og grupper; og de personer, der har en stor symbolsk kapital, eksempelvis adelen, dvs. etymologisk set dem, der er erkendt og anerkendt, er i en position, hvor de kan påtvinge den værdiskala, som er mest favorabel for deres produkter. Det kan de især, fordi de i vore samfund har et de facto monopol på institutioner, der ligesom uddannelsessystemet officielt etablerer og garanterer rang. På den anden side må symbolsk kapital officielt sanktioneres, garanteres og etableres juridisk ved en officiel udnævnelse. Officiel udnævnelse, med andre ord den handling, hvor man tildeler nogen en titel for en socialt anerkendt kvalifikation, er en af de mest typiske demonstrationer af det monopol på legitim symbolsk vold, som tilhører staten eller dens repræsentanter. Et diplom eller et eksamensbevis er en universelt anerkendt og garanteret symbolsk kapital, der er gyldigt på alle markeder. Som en officiel definition på en officiel identitet frig $\varnothing r$ det indehaveren fra den symbolske 'alles kamp mod alle' ved at påtvinge det universelt anerkendte perspektiv.

Staten, som producerer den officielle klassifikation, er i en vis forstand den højeste domstol, som Franz Kafka refererer til i Processen, når Block siger om en af advokaterne, der påstår at være en af de 'store advokater': "Enhver kan naturligvis kalde sig selv 'stor', hvis han har lyst, men i denne sag må retstraditionen afgøre det." (Kafka, 1953, s.197). Videnskaben behøver ikke at vælge mellem relativisme og absolutisme: Sandheden om den sociale verden står på spil i (kampene mellem agenter, som er ulige udstyret til at nå en absolut, dvs. en selvbekræftende, vision: Set i perspektiv tildeler legaliseringen af symbolsk kapital en absolut, universel værdi, som på denne måde frig $\varnothing r$ den fra en relativitet, der per defimtion er uadskillelig fra ethvert synspunkt, forstået som et syn set fra et bestemt punkt i det sociale rum.

Der er et officielt synspunkt, som er de officielles synspunkt og som udtrykkes i officiel diskurs. Denne diskurs, som Aaron V. Cicourel har vist det, opfylder tre funktioner: For det første udfører den en diagnostik, dvs. en erkendelseshandling, som forstærker anerkendelse, og som ganske ofte tenderer mod at bekræfte, hvad en person eller en ting er, og hvad den er, universelt betragtet, for en hvilken som helst person og således objektivt set. Det er, som Kafka tydeligt så det, en næsten guddommelig diskurs, der tildeler enhver en identitet. For det andet administrerer den gennem direktiver, ordrer, forskrifter etc. og fortæller, hvad folk skal gøre, afhængig af, hvad de er. For det tredje fortæller den i autoriserede optegnelser, såsom politirapporter, hvad folk i virkeligheden har gjort. I hvert tilfælde påtvinger den et synspunkt, institutionens, især gennem spørgeskemaer, officielle formularer etc. Dette synspunkt opstilles som et legitimt synspunkt, dvs. som et synspunkt, enhver skal anerkende i det mindste inden for et givet samfunds grænser. Statens repræsentant er et opbevaringssted for fornuft: Officielle udnævnelser og eksamensbeviser har gerne en universel værdi på alle markeder. Den mest typiske effekt af denne 'raison d'Etat', statsfornuft, er kodifikationseffekten, som fungerer ved handlinger så simple som tildelingen af et diplom: En ekspert, læge, jurist el.lign. er en, der er udpeget til at producere et synspunkt, som overskrider det personlige synspunkt, i form af lægeerklæringer; certifikater, der udtrykker kompetence eller 
inkompetence; et synspunkt, som tildeler indehaveren af certifikatet universelt anerkendte rettigheder. Staten optræder på denne måde ligesom centralbanken, idet den garanterer alle certifikater. Man kan sige om staten med de termer Leibniz brugte om Gud, at den er det "geometriske locus for alle perspektiver". Det er derfor man må generalisere Webers berømte formel og i staten se indehaveren af monopolet på legitim symbolsk vold. Eller mere præcist: Staten er en dommer, endda en meget magtfuld dommer, i kampene om dette monopol.

Men i kampen om produktionen og påtvingelsen af en legitim vision om den sociale verden opnår indehaverne af den bureaukratiske autoritet aldrig et absolut monopol, ikke en gang, når de føjer videnskabens autoritet til deres bureaukratiske autoritet, som stats $\varnothing$ konomer gør det. Faktisk er der i et samfund altid konflikter mellem symbolske magter, som har til hensigt at påtvinge modparten deres vision om den legitime inddeling, dvs. konstrueringen af grupper. Symbolsk magt er i denne mening en magt til "verdensskaben". Verdensskaben består ifølge Nelson Goodman i at "adskille og genforene, ofte i den samme operation", i at udføre en dekomposition eller analyse og en komposition eller syntese, ofte ved brug af etiketter. Social klassifikation fungerer oftest, som det er tilfældet i arkaiske samfund, gennem dualistiske operationer (maskulin/ feminin, høj/lav, stærk/ svag), organiserer opfattelsen af den sociale verden og kan under særlige omstændigheder virkelig organisere verden selv.

Vi kan nu begynde at undersøge, under hvilke betingelser en symbolsk magt kan blive til en konstituerende magt, idet vi med John Dewey tager termens såvel filosofiske som politiske mening i betragtning. Dvs. en magt til at bevare eller ændre de objektive principper for forening eller adskillelse, ægteskab eller skilsmisse, association eller dissociation, som fungerer i den sociale verden; en magt til at bevare eller omforme nuværende klassifikationer vedrørende $k \varnothing n$, nation, region, alder og social status; en magt viderebragt af de ord, som bruges til at betegne eller beskrive individer, grupper eller institutioner.

For at forandre verden må man ændre måden, hvorpå verden skabes, dvs. visionen om verden og de praktiske operationer, hvor grupper produceres og reproduceres. Symbolsk magt, hvis mest eksemplariske form ses i magten til at producere grupper (allerede etablerede grupper, som må anerkendes, eller grupper, som stadig mangler at blive etableret, som det Marx'ske proletariat), er baseret på to betingelser. For det første må symbolsk magt, som enhver form for diskurs, der undviger noget, baseres på besiddelsen af symbolsk kapital. Magten til at påtvinge andre en vision, gammel eller ny, om social inddeling, afhænger af den sociale autoritet opnået i forudgående kampe. Symbolsk kapital er en anerkendelse, det er styrken tildelt dem, der har opnået tilstrækkelig anerkendelse til at være i en position, hvor de kan forlange yderligere anerkendelse: Sådan kan den konstituerende magt - magten til ved mobilisering at danne en ny gruppe, eller til at lade den eksistere ved prokuration, ved at tale på dens vegne, som en autoriseret talsmand - kun opnås ved afslutningen af en lang institutionaliseringsproces, for enden af hvilken der vælges en repræsentant, som fra gruppen modtager magten til at danne gruppen.

For det andet afhænger symbolsk effektivitet af, i hvilken grad den foreslåede vision er baseret på realiteter. Helt indlysende kan konstruktionen af grupper ikke være en konstruktion ex nihilo. Den har desto st $\varnothing$ rre chance for succes, jo mere den er funderet i virkeligheden, ergo som jeg har sagt i de objektive affiniteter mellem mennesker, som må bringes sammen. Teori-effekten er desto mere magtfuld, jo mere adækvat teorien er. Symbolsk magt er en magt til at skabe ting med ord. Det er kun hvis den er sand, dvs. adækvat med ting, at en beskrivelse kan skabe ting. I denne mening er symbolsk magt en magt til indvielse eller åbenbaring, en magt til at skjule eller åbenbare ting, som allerede er der. Betyder det, at den ikke gør noget? Ifølge Nelson Goodman begynder en konstellation i virkeligheden først at eksistere, når den er selekteret og beskrevet som sådan for dem, som er en del af den, og også for andre; en gruppe, en klasse, et køn, en region eller en nation 
begynder først at eksistere, når den skiller sig ud fra andre grupper gennem erkendelse og anerkendelse i overensstemmelse med et eller andet princip.

Det er således, håber jeg, lettere at forstå, hvad der er på spil i kampen om eksistensen eller ikkeeksistensen af klasser. Kampen om klassifikationer er en fundamental del af klassekampen. Magten til at påtvinge en vision om inddelingerne, dvs. magten til at synliggøre og eksplicitere sociale inddelinger, som er implicitte, er den politiske magt par excellence: Det er magten til at danne grupper, til at manipulere samfundets objektive strukturer. Ligesom det er tilfældet med konstellationer, skaber den ud $\varnothing$ vende magt betegnelser og nomineringer i en oprettet, konstitueret form, (dvs. som et 'korpo', en corporatio, som de middelalderlige kanonister, studeret af Hermann Kantorowicz, sagde), det der ind til da kun eksisterede som en collectio personarum plurium., en samling af mange personer, en rent additiv gruppe af individer, der blot var placeret side om side.

Hvis vi genkalder os det hovedproblem, jeg har forsøgt at forklare i dag, der handler om, hvordan man kan skabe ting (dvs. grupper) med ord, konfronteres vi med et sidste spørgsmål, spørgsmålet om mysteriet om ministeriet, som kanonisterne yndede at formulere det: Hvordan bliver talsmanden udstyret med fuldmagt til at handle og tale på vegne af gruppen, som han producerer gennem magien i sloganet, feltråbet eller kommandoen, og ved sin blotte eksistens som en inkarnation af gruppen? Som kongen i de arkaiske samfund, rex, der ifølge Emile Benveniste har til opgave at regere fines og at regere sacra, at opspore og statuere grænserne mellem grupper, og derved få dem til at eksistere som sådanne, er lederen af en fagforening eller et politisk parti, tjenestemanden eller den statsautoriserede ekspert, en af så mange personificeringer af en social fiktion, som de giver eksistens i og med selve deres væren, og fra hvilken de til gengæld modtager deres magt. Talsmanden er stedfortræder for gruppen, som udelukkende eksisterer gennem denne bemyndigelse, og som handler og taler gennem ham. Han er personificeringen af gruppen. Som kanonisterne siger: Status, positionen, er magistratus, magistraten, som optager den; eller som Louis XIV sagde: "L'État, c' est moi", "Staten, det er mig"; eller igen, med Robespierres ord, "Je suis le peuple", "Jeg er folket". Klassen (eller folket, eller nationen, eller en hvilken som helst anden social realitet, som ikke kan begribes på nogen anden måde) eksisterer, hvis der findes mennesker, der udgør klassen ved det blotte faktum, at de kan tale offentligt, officielt på klassens vegne - og at de bliver anerkendt herfor og får retten hertil af deres folk. Selve folket betragter herved sig selv som medlemmer af klassen, folket eller nationen, eller af en hvilken som helst anden social virkelighed, og betragter den konstruktion som en realitet.

Jeg håber, at jeg inden for grænserne af min sproglige kapacitet, har overbevist jer om, at kompleksiteten ligger i den sociale virkelighed og ikke i det noget dekadente $\varnothing$ nske om at sige komplicerede ting. "Det enkle", plejede Gaston Bachelard at sige, "er aldrig andet end det forenklede". Han demonstrerede, at videnskab aldrig har gjort fremskridt, undtagen ved at sætte spørgsmålstegn ved enkle ideer. Et tilsvarende spørgsmål, forekommer det mig, trænger til at blive stillet til de sociale videnskaber på grund af det faktum - blandt alle dem jeg har nævnt - at vi for let $\emptyset$ nsker at tilfredsstille os selv med de indlysende billeder, vi udleder af vores ' sund fornuft-erfaring' eller vores fortrolighed med en videnskabelig tradition.

\section{Referencer}

Bourdieu, P. (1990). Social space and symbolic power. I: In other Words, essays towards a Reflexive Sociology. Cambridge: Polity Press.

Bourdieu, P. (1988). The Categories of Professorial Judgement. I: Homo Academicus. Cambridge: Polity Press.

Bourdieu, P. (1979). La Distinction. Critique sociale du jugement. Paris: Éditions de Minuit. 
Bourdieu, P. \& Passeron, J-C. (1970). La reproduction. Éléments pour une théorie du système d'enseignement. Paris: Éditions de Minuit.

Bourdieu, P., Passeron, J-C. \& de Saint Martin, M. (red.)(1965). Rapport pédagogique et communication. Paris: Mouton.

Callewaert, S., Munk, M., Nørholm, M. og Petersen K.A. (red.)(1994-2008): Pierre Bourdieu. Centrale tekster inden for sociologi og kulturteori. København: Akademisk Forlag/Frydenlund.

Kafka, F. (1953). The Trial. Harmondsworth: Penguin Books.

Schutz, A. (1973). Collected Papers. Vol. I. The Problem of Social Reality. The Hague: Martinus Nijhoff. Thompson, E.P. (1963). The Making af the English Working Class. Toronto: Doubleday. 